\title{
Dynamic CGE Model of the Chinese Economy for Fiscal and Financial Policy Analysis*
}

\author{
Keshab Bhattarai \\ University of Hull, Hull, UK
}

\begin{abstract}
China is to become the largest economy in the world by 2020 according to the IMF forecasts. Annual growth rates of output remained around 9.3 percent on average during 1980 to 2015. It was made possible by the accumulation capital with steady flows of investment on average around 49.5 percent of GDP, an increase in the human capital index from 1.8 to 2.6 in the country that has the largest population among all countries. Current account surplus stood around 3.4 percent of GDP. Such growth rates were possible due to macroeconomic stability. Market friendly growth strategy however has led to a sharp increase in the income and consumption inequality. Inequality is deeper in the rural areas than in the urban areas. A representative household in the richest quintile earns eight times more than an average household in poorest quintile. This is five times more in urban areas. The Gini coefficient was around 0.48. By this measure China has become the most unequal economy in the world. Similar disparities remain across provinces of China; per capita income of Tianjin was 99,600 Yuan compared to 22,921 Yuan of Guizhou. Chinese government has used public spending to create economic infrastructure and public services. The share of public spending and revenue has reached around 30 percent of GDP in China in recent years. Share of local government has risen steadily over years from 53 percent to 86 percent in 2013. Efficiency in the local governance thus is essential for correcting economic and social problems in China. VAT, corporation tax, business tax, consumption tax, income tax, and tariffs are important sources of revenue. In 2013, these contributed to 26, 20, 16, 7, 6, and 2 percents of total revenue respectively. Compared to advance countries Chinese tax system still seems very regressive as the income tax contributes to the very small proportion of the total revenue. It is welcome to see that the share of VAT decreased from 36 to 26 percent and tax in corporate income tax rose from eight to 20 percent but the very low income tax that accounts about 6 percent of total revenue, has caused income inequality to deteriorate. The adverse consequences of tax composition are to some extent mitigated by a more reasonable structure of public spending. Education, social safety, agriculture, public services, community, transport, and health had 18, 12, 11, 11, 10, 7, and 7 percent of public spending respectively.
\end{abstract}

Keywords: China, dynamic CGE, fiscal policy

\section{Introduction}

China is becoming the largest economy in the global economy. It is important to understand the structure

*This paper is based on lectures given to three delegations from China to the University of Hull Business School during 2014-2016 academic years (see Appendix B).

Keshab Bhattarai, Ph.D., senior lecturer, Business School Faculty of Business, University of Hull, Hull, UK.

Correspondence concerning this article should be addressed to Keshab Bhattarai, Business School Faculty of Business, University of Hull, Cottingham Road, Hull, HU6 7RX, UK. 
and functioning of the Chinese economy in order to appreciate the patterns of growth not only among the emerging economies but the global economy as a whole. This requires proper assessment of the markets in China particularly its process of production, consumption and trade and long public policies in china that are brought to influence the growth and allocation process in China. Such comprehensive understanding requires a macroeconomic model that is founded properly in the micro-foundations both in production and consumption sides of the economy.

Market friendly growth strategyin China has led to a sharp increase in the income and consumption inequality. Inequality is deeper in the rural areas than in the urban areas. A representative household in the richest quintile earns eight times more than an average household in poorest quintile. This is five times more in urban areas. The Gini coefficient was around 0.48. By this measure China has become the most unequal economy in the world. Similar disparities remain across provinces of China; per capita income of Tianjin was 99,600 Yuan compared to 22,921 Yuan of Guizhou.

Policy makers in China now are concerned about how the various measures of fiscal policy should be used to reduce income inequality among individuals and regions, to maintain steady rate of growth and achieve the macroeconomic stability in coming years. A dynamic CGE model, calibrated on the micro-consistent dataset of the Chinese economy is very essential in order to assess alternative policy scenarios to sustain growth with reasonable distribution of income.

Aim of this paper is to introduce the DCGE model of the Chinese economy as well as the datasets used to calibrate this model. It also aims to find out the evolution of the Chinese economy for the next century given by the current structure of the economy and the set of parameters derived from the existing time series.

The DCGE model constructed in the Hull University Business School has more than 20,800 variables to represent output, investment, capital accumulation, employment, relative prices, exports, imports, tax payments as well as to compute the level of welfare of households in the economy. This model solved balancing demand and supply with continuous adjustment in the relative prices, investment, and capital accumulation. The major parameters of the model include the elasticities of substitution in production, consumption, and trade. It contains flexibility of markets in goods and services or over pricing or mark up behaviour of firms. This is truly a micro-founded macro model of the Chinese economy designed to explain growth and redistribution simultaneously. Cost of tax and transfer distortions across firms and households can be measured by simulating the model. Current version of model analysis is based on changes on taxes on capital and labour inputs. This model precisely measures the economy wide impacts of policy choices of the government (see results in excel files or power point slides).

Model will be extended to analyse issues of pensions or social security and the aging society, and consequences of debt accumulation in the public and private sectors; to explain the consequences of public policy choices of the central and local governments.

\section{Stylized Facts}

\section{Growth and Size of the Chinese Economy}

China is becoming the largest economy in the World by 2020. This is possible because of continuous growth in China since 1980s, after China adopted the export oriented growth strategy. Saving and investment ratios to GDP around 49 percents have made it possible; FDI flows also contributed to this growth. Level of per capita income is still quite low compared to advanced countries. Analyses are based on results from the dynamic general equilibrium model of China calibrated to the input-output tables of these economies. 


\section{Macro Ratios}

Real GDP of China has increased 25 times since 1978 (Figure 1) and the GDP per capita has increased by almost 20 times since then (Figure 2). Such a growth in GDP was possible by raising the share of investment from 20 percent to almost up to 50 percent of GDP. The reduced is the consumption share from 60 percent of GDP to 30 percent (Figure 3). The phenomenal rate of capital formation was accompanied by rising degree of openness. From a closed economy, almost no trade export ratio and import ratio increased above 20 percent of GDP. Public consumption has remained constant.

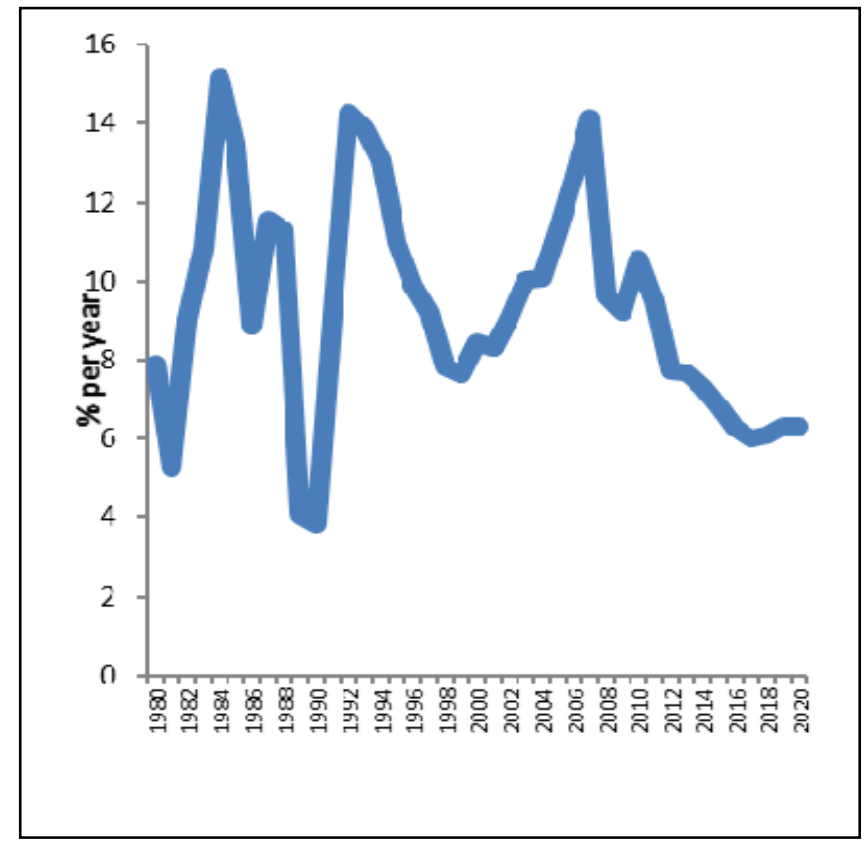

Figure 1. Growth rate of GDP in China.

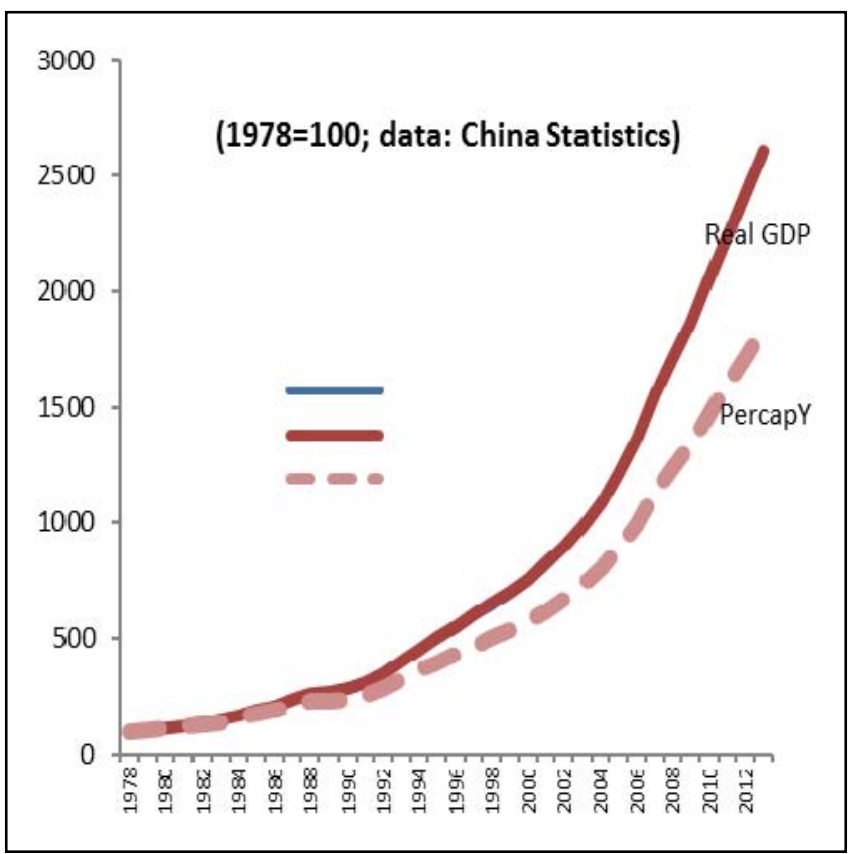

Figure 2. Levels of GDP and per capita income. 


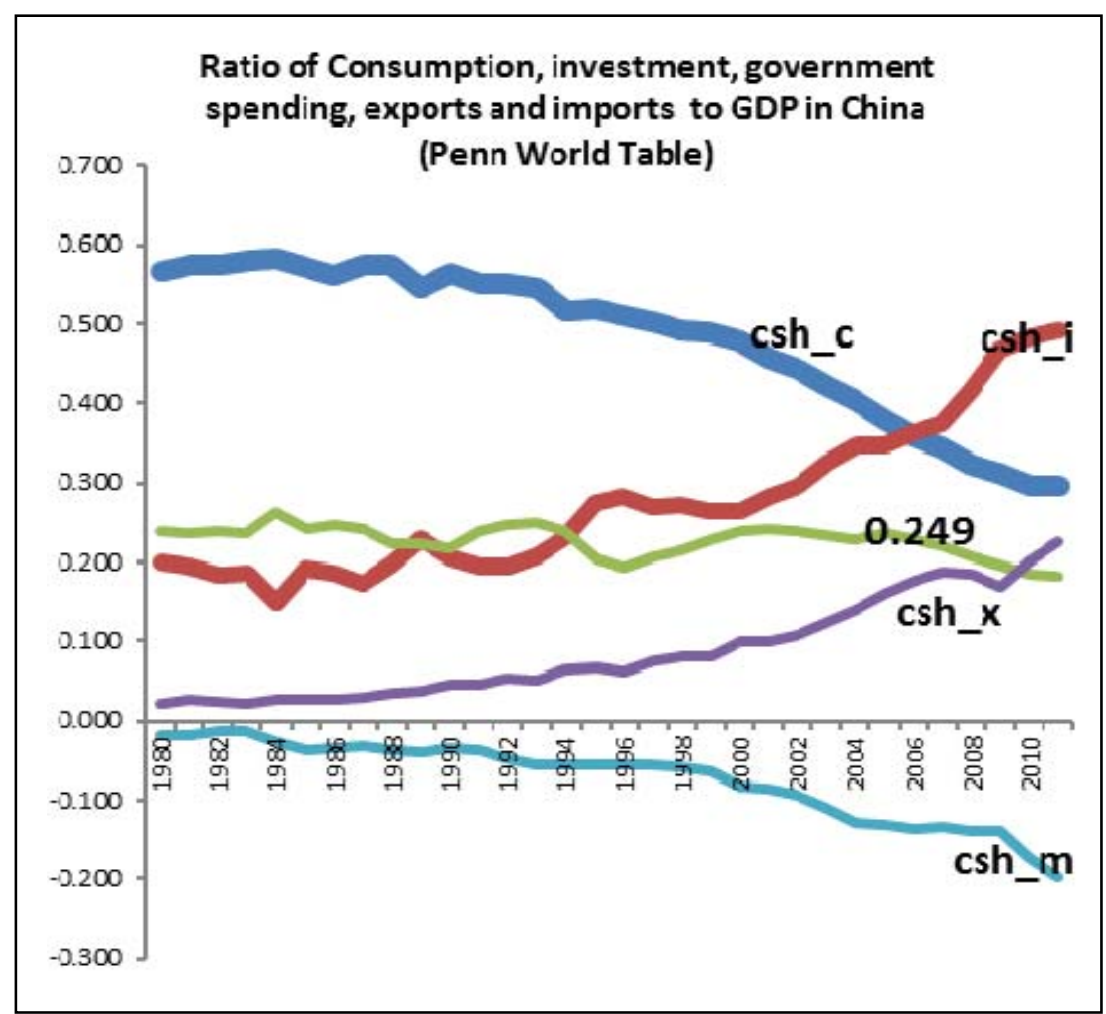

Figure 3. Ratio of consumption, investment, government spending, exports and imports to GDP in China (Penn World Table).

\section{Current Account Balance}

Export led growth strategy became quite successful between 2004 and 2012. Current account surplus led to the accumulation of the foreign currency reserves (Figure 4). This made it possible to finance investment in heavy industries and infrastructure and this is the reason for increase in the investment GDP ratio above 50 percent as shown in Figure 3.

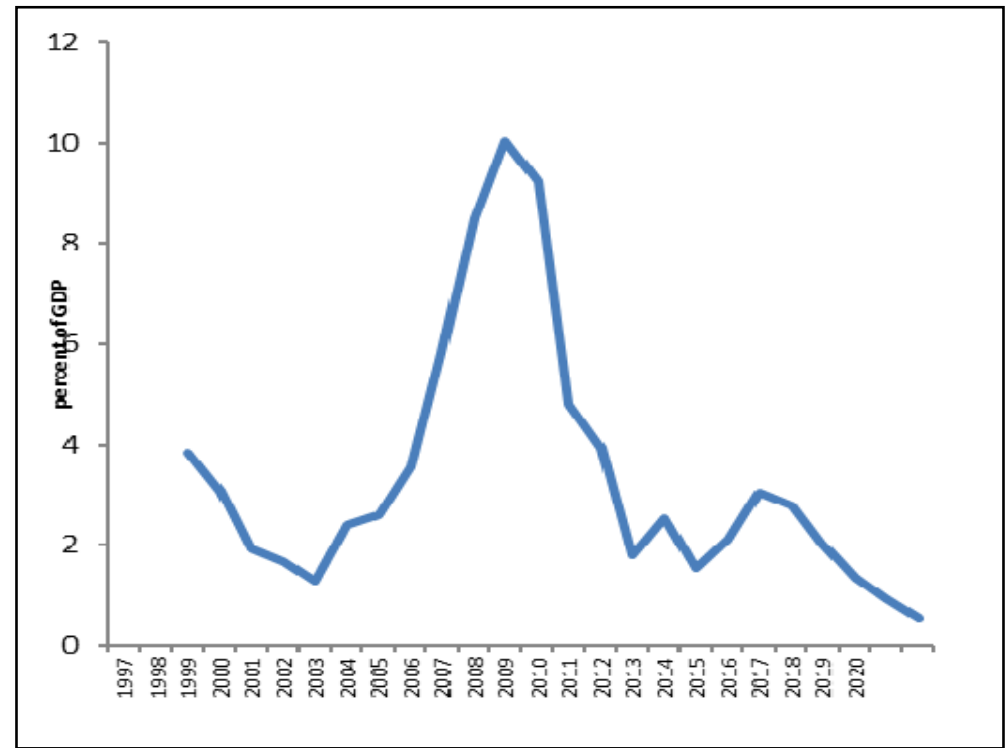

Figure 4. Ratio of current account balance to GDP in China. 


\section{Structure of Income and Expenditure}

Wages and salaries constitute above 57 percent of household income in China. Recently the share of business income (19\%) and transfers (16\%) are rising in their importance (Figure 5). Property income (8\%) is rising in recent years.

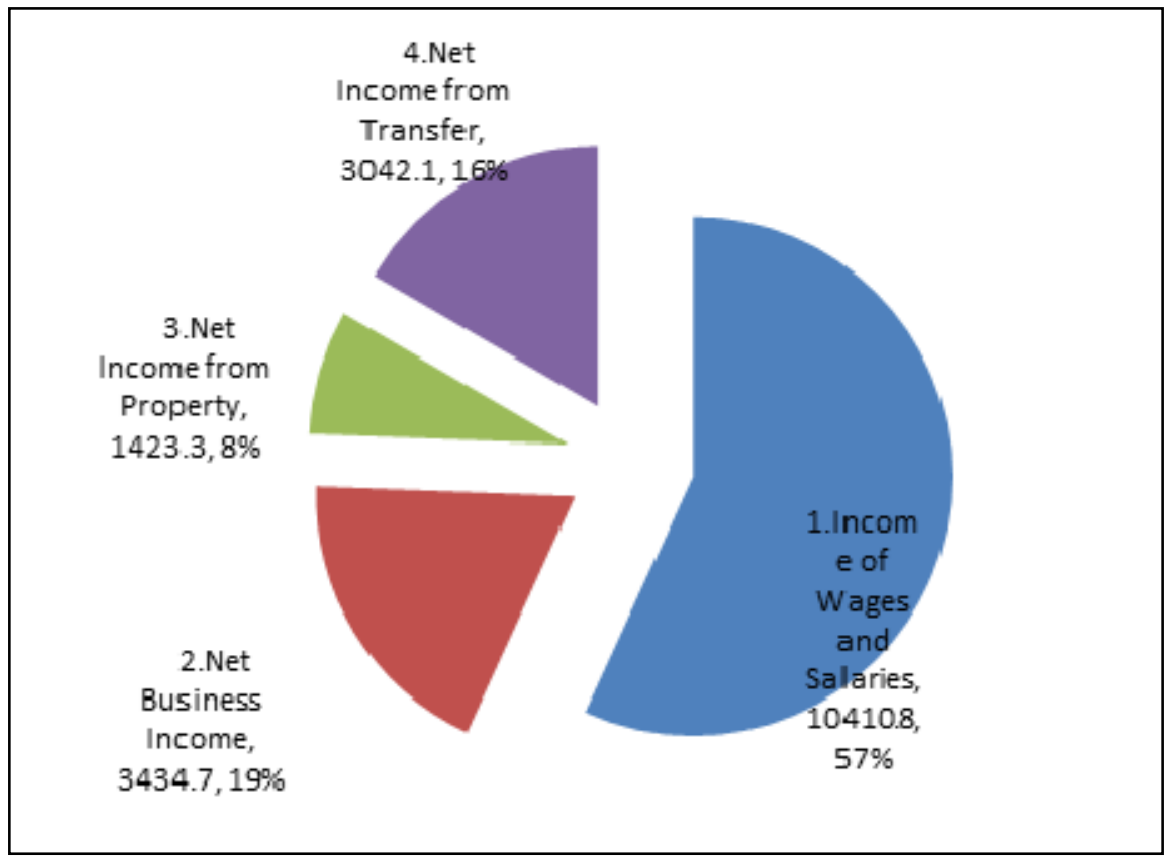

Figure 5. Composition of income of households in China, 2013.

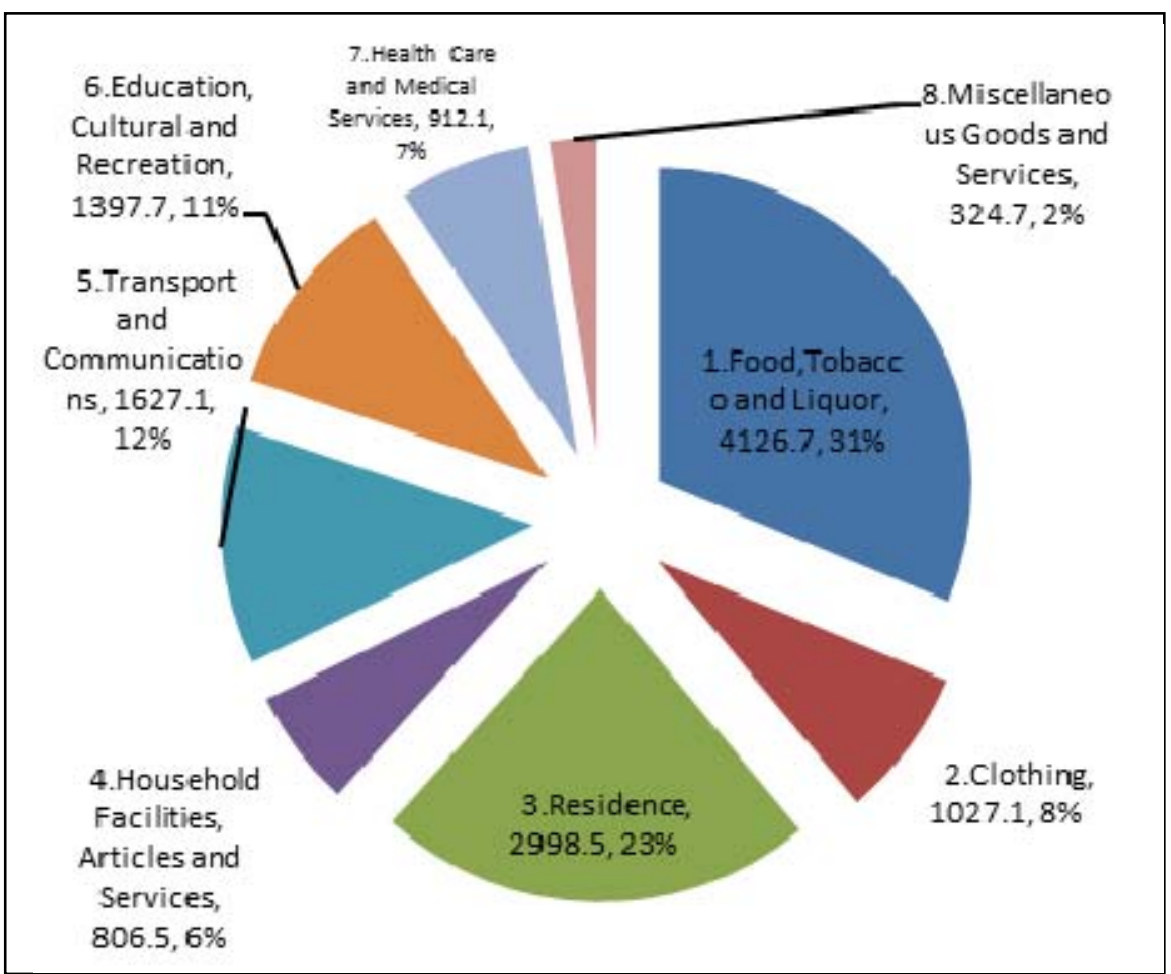

Figure 6. Composition of household expenditure in China, 2013. 
More than 50 percent of household expenditure is on food, tobacco, and liquor (31\%) and cost of residence (23\%) as shown in Figure 6. Transportation and communication (12\%) and education and recreation income (11\%) take about the same size of household expenditure. Clothing (6\%), health, and medical care (7\%) are other items of the household spending.

\section{Inequality}

Income inequalities have increased very fast in China in the last three decades as it is evident from the Gini coefficients at 48 percent in 2014 (Figure 7). Bhattarai and Chen (2013) are concerned that "the fruits of growth have not been equally distributed among people living in rural and urban areas. Population, consumption and income have grown faster in urban than in rural areas".

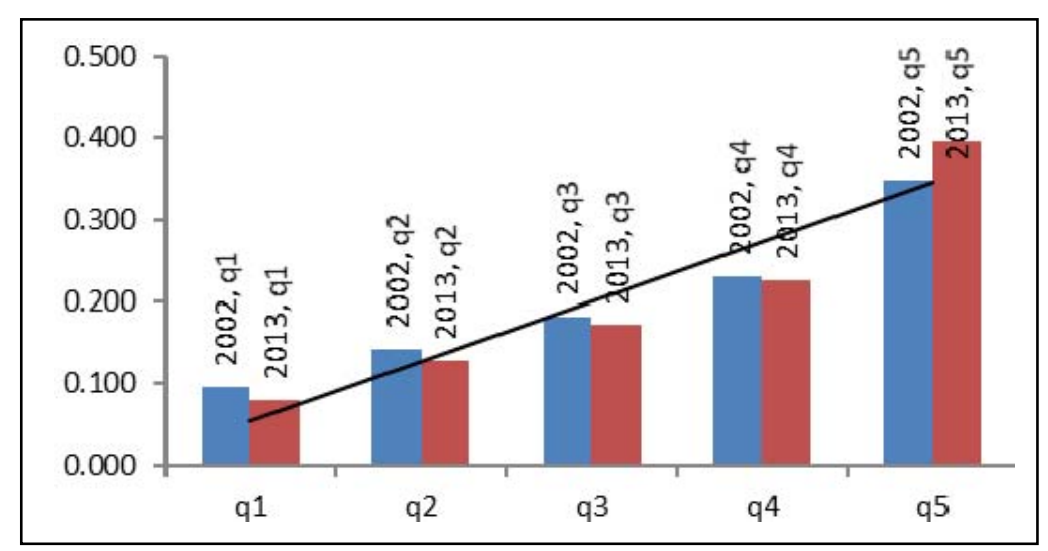

Figure 7. Quintile share of per capita income: Urban households, 2002 and 2013.

\section{Public Finance}

Size of the public has been growing with the economy in recent years (Figure 8). They are nearly 30 percent of GDD now. These have declined from 25 to 10 from 1980 to 1995. The absolute size of the revenue and spending has been growing steadily (Figure 9). Indirect tax such as VAT is becoming more important source of revenue with the growth of the economy (Figure 10). Other two major contributors to the revenue have been corporate and business taxes. These are followed by consumption and income taxes and tariffs. More details on the structure of tax revenue are given on Table 1 and Figure 10.

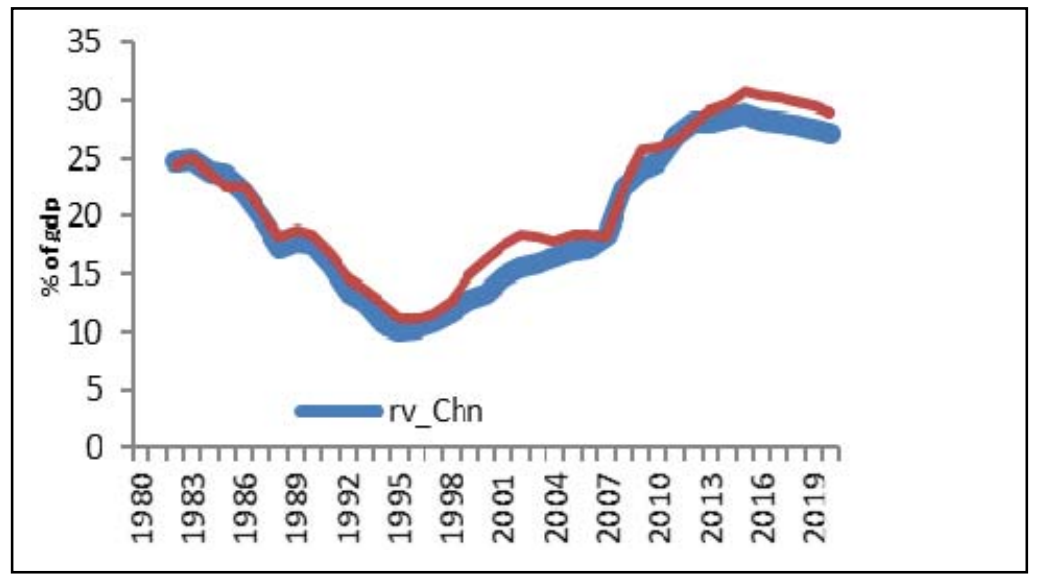

Figure 8. Ratio of revenue and government spending to GDP. 


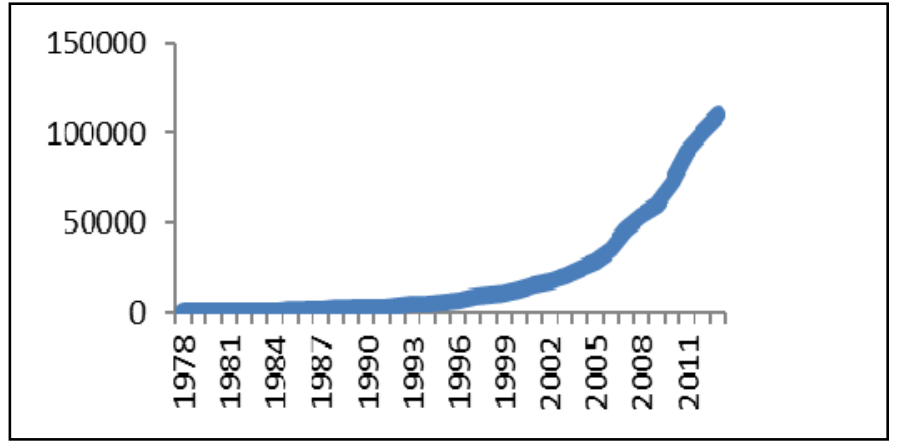

Figure 9. Total revenue in China (100 million Yuan).

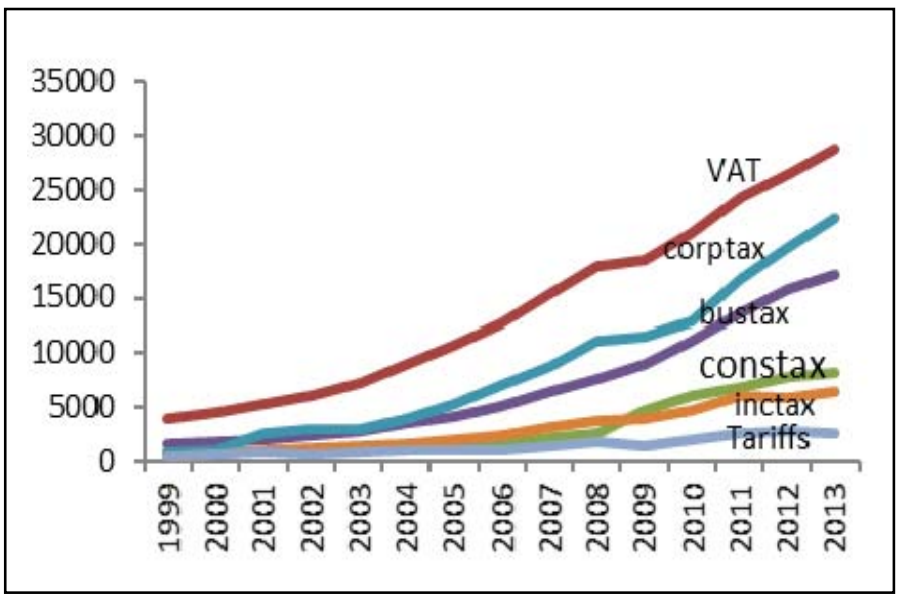

Figure 10. Source of tax revenue in China.

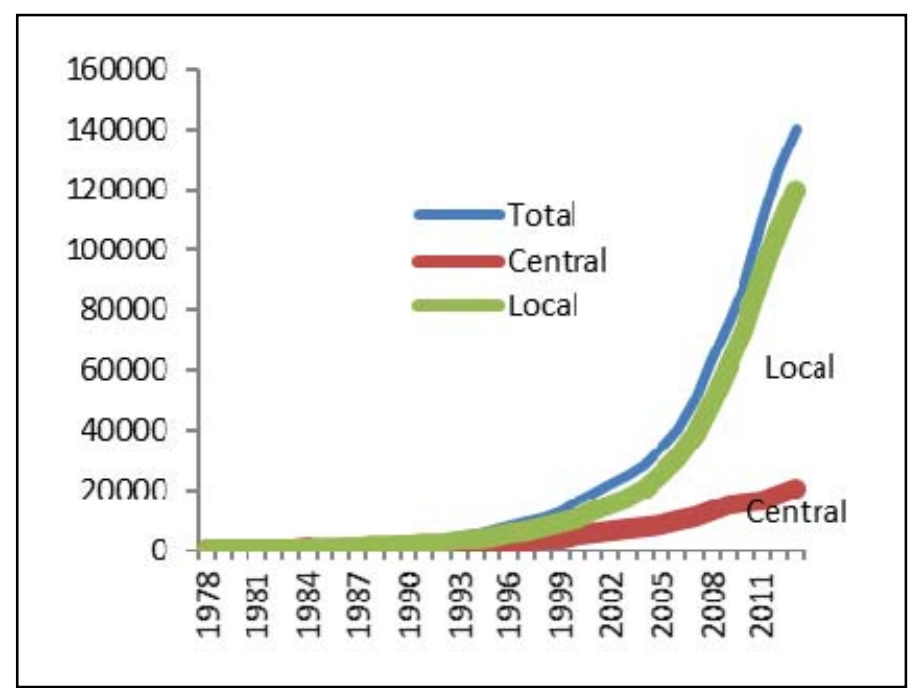

Figure 11. Central and local government spending (100 million Yuan).

Consequences of faster rate of rise in public spending over that of revenue are reflected in increasing amount of borrowing each year at central and local levels (Figure 12a). This has led to a continuous increase in size of public debt (Figure 12b). The debt GDP ratio is now above 50 percent in China. Rising debt is not a good sign as it not only weakens government ability to manoeuvre public finance to stabilise or spur growth, but also imposes burdens to the coming generations. 


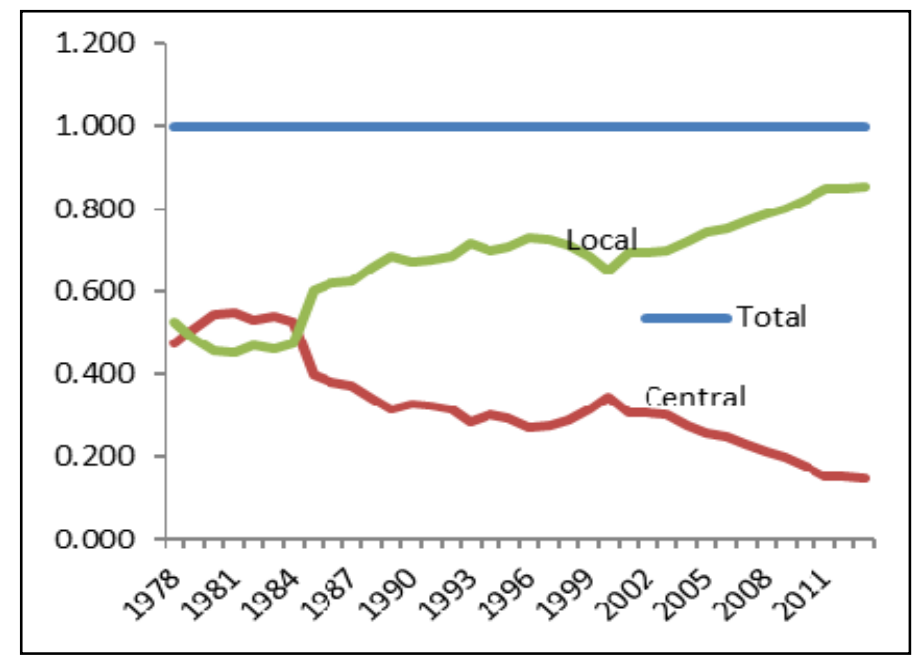

Figure 12a. Share of public spending of the central and the local government.

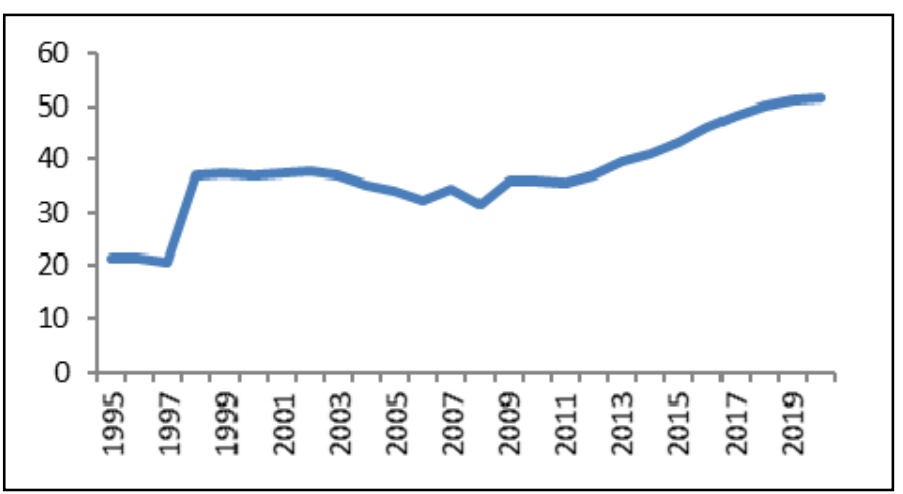

Figure 12b. Debt GDP ratio in China.

Table 1

Sources of Tax Revenue

\begin{tabular}{llllllll}
\hline & Total & VAT & Consumption tax & Business tax & Corporation tax & Income tax & Tariffs \\
\hline 1999 & $10,682.58$ & $3,881.87$ & 820.66 & $1,668.56$ & 811.41 & 413.66 & 562.23 \\
2000 & $12,581.51$ & $4,553.17$ & 858.29 & $1,868.78$ & 999.63 & 659.64 & 750.48 \\
2001 & $15,301.38$ & $5,357.13$ & 929.99 & $2,064.09$ & $2,630.87$ & 995.26 & 840.52 \\
2002 & $17,636.45$ & $6,178.39$ & $1,046.32$ & $2,450.33$ & $3,082.79$ & $1,211.78$ & 704.27 \\
2003 & $20,017.31$ & $7,236.54$ & $1,182.26$ & $2,844.45$ & $2,919.51$ & $1,418.03$ & 923.13 \\
2004 & $24,165.68$ & $9,017.94$ & $1,501.90$ & $3,581.97$ & $3,957.33$ & $1,737.06$ & $1,043.77$ \\
2005 & $28,778.54$ & $10,792.11$ & $1,633.81$ & $4,232.46$ & $5,343.92$ & $2,094.91$ & $1,066.17$ \\
2006 & $34,804.35$ & $12,784.81$ & $1,885.69$ & $5,128.71$ & $7,039.60$ & $2,453.71$ & $1,141.78$ \\
2007 & $45,621.97$ & $15,470.23$ & $2,206.83$ & $6,582.17$ & $8,779.25$ & $3,185.58$ & $1,432.57$ \\
2008 & $54,223.79$ & $17,996.94$ & $2,568.27$ & $7,626.39$ & $11,175.63$ & $3,722.31$ & $1,769.95$ \\
2009 & $59,521.59$ & $18,481.22$ & $4,761.22$ & $9,013.98$ & $11,536.84$ & $3,949.35$ & $1,483.81$ \\
2010 & $73,210.79$ & $21,093.48$ & $6,071.55$ & $11,157.91$ & $12,843.54$ & $4,837.27$ & $2,027.83$ \\
2011 & $89,738.39$ & $24,266.63$ & $6,936.21$ & $13,679.00$ & $16,769.64$ & $6,054.11$ & $2,559.12$ \\
2012 & $100,614.28$ & $26,415.51$ & $7,875.58$ & $15,747.64$ & $19,654.53$ & $5,820.28$ & $2,783.93$ \\
2013 & $110,530.70$ & $28,810.13$ & $8,231.32$ & $17,233.02$ & $22,427.20$ & $6,531.53$ & $2,630.61$ \\
\hline
\end{tabular}

Source: China Statistics Yearbook, 2015. 


\section{Central and Local Provision of Public Goods}

Central government is responsible for central public goods such as defence, administration of executive, national networks for transports and communication, legislative and judiciary services at the central level, management of natural calamities and disasters. Local authorities provide majority of public goods such as education and health, utilities and city or rural developmental activities (Figure 14). Over years size of the local services has increased substantially relative to that of the central government (Figure 11). While the share of local public sector has risen from around 50 percent to 85 percent there has been corresponding decline of the central public sector from 50 percent to 15 percent (Figure 12a). This shows how the economic decentralisation process is improving from 1980 up to recent years. This trend still may continue further in coming years.

\section{Sectoral Structure of the Chinese Economy}

Construction has emerged as the largest production sector in China in recent years (8 trillion, Figure 13a) and it is about 10 percent of the GDP (Figure 13b). Each year new national highways, railways, dockyards, airports, hospitals and educational institutions, factories, tall apartment buildings are being added through-out China. May mega cities are emerging each year to accommodate 1.3 billion people. Then machinery and chemical are the next important sectors each of size 5.5 trillion Yuan. So is the agriculture. The research and development is the smallest sector of 188 billion Yuan.

Public expenditure in the economy is spent most in the education (17.5\%) followed by social services (11.6\%), agriculture (10.7\%) followed by public services, community, transport, health, public security, information, housing , environment, other, science and technology, sports, land and commercial services.

\section{Regional Disparity}

The economic size of provinces in China varies enormously. While the largest province Guangdong had the provincial GDP around 5.7 trillion Yuan, the smallest province by GDP Tibet had only 70 billion Yuan (Figure 15a). Tibet's GDP was about 1.2 percent of Guangdong (Figure 15b). The discrepancy in per capita income was about five times between the richest and poorest provinces. Per capita income in Tianjin was almost 100 thousand Yuan but Guizhou had only 23 thousand Yuan (Figure 16). Thus the difference in living standard among provinces is as high as five times on average.

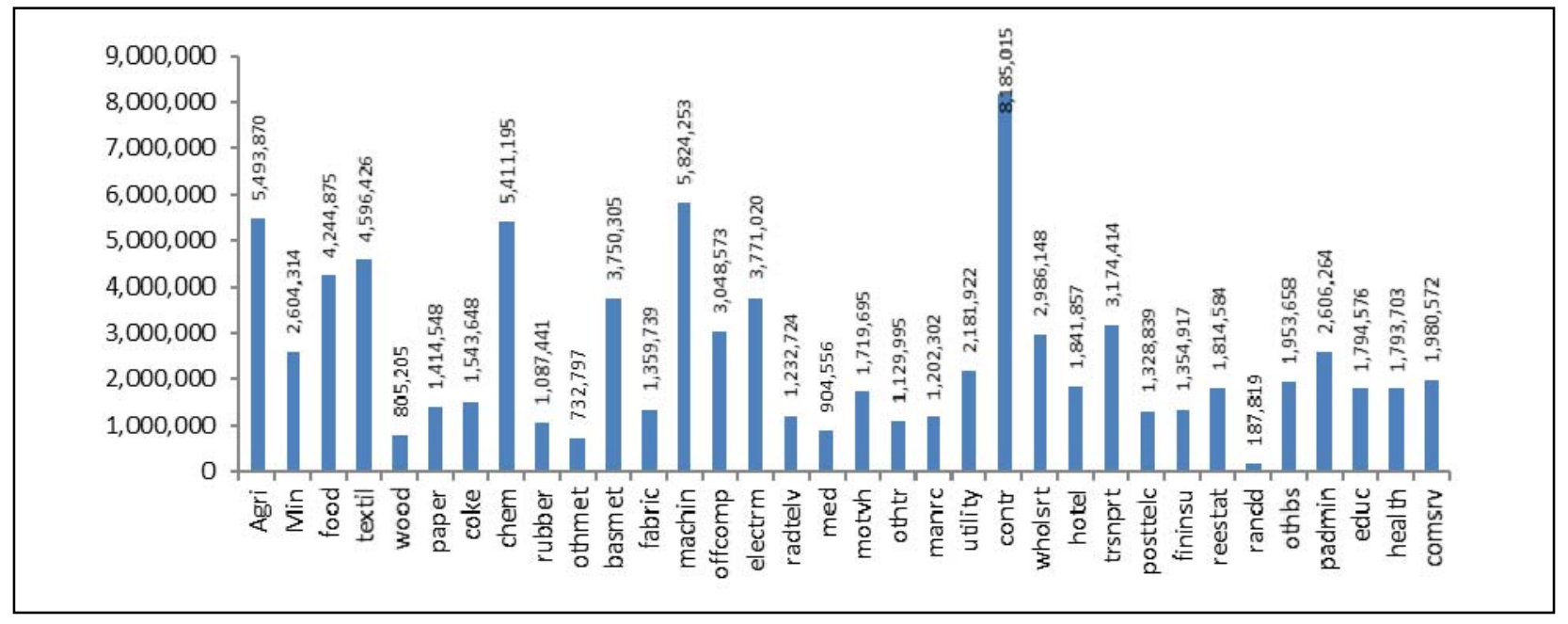

Figure 13a. Sectoral composition of output in China, 2013 (in million Yuan). 


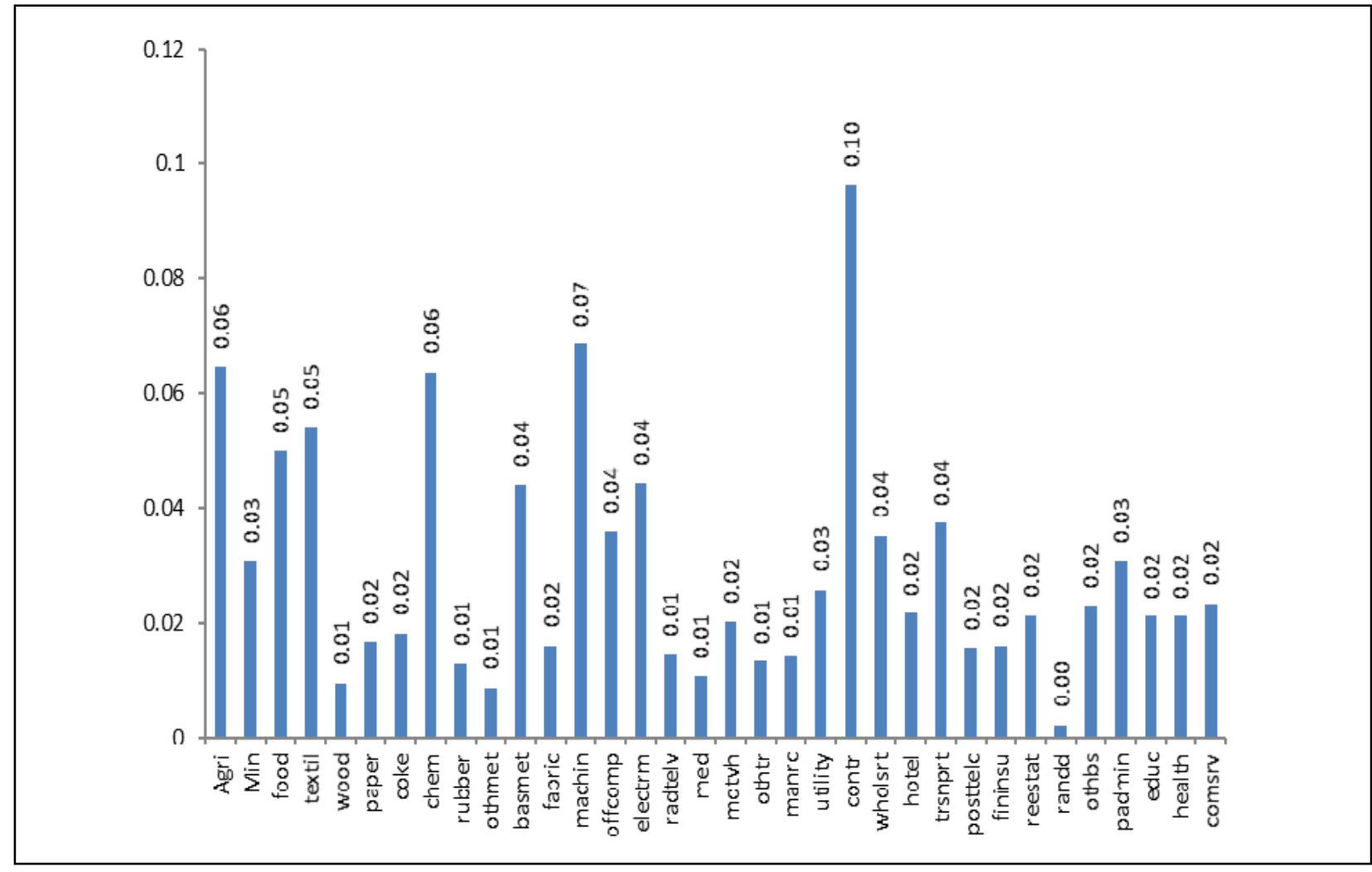

Figure 13b. Sectoral composition of output in China, 2013 (in percent).

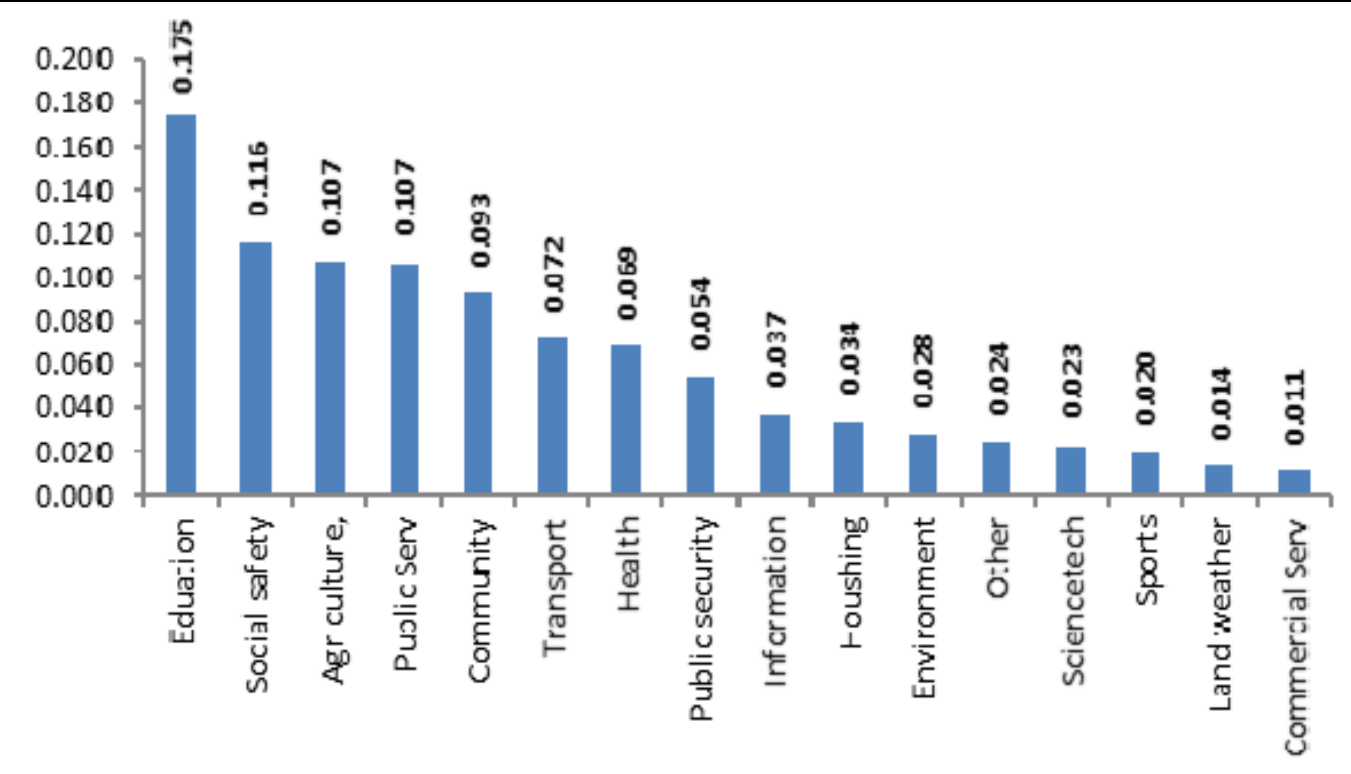

Figure 14. Items of public expenditure, 2013. 


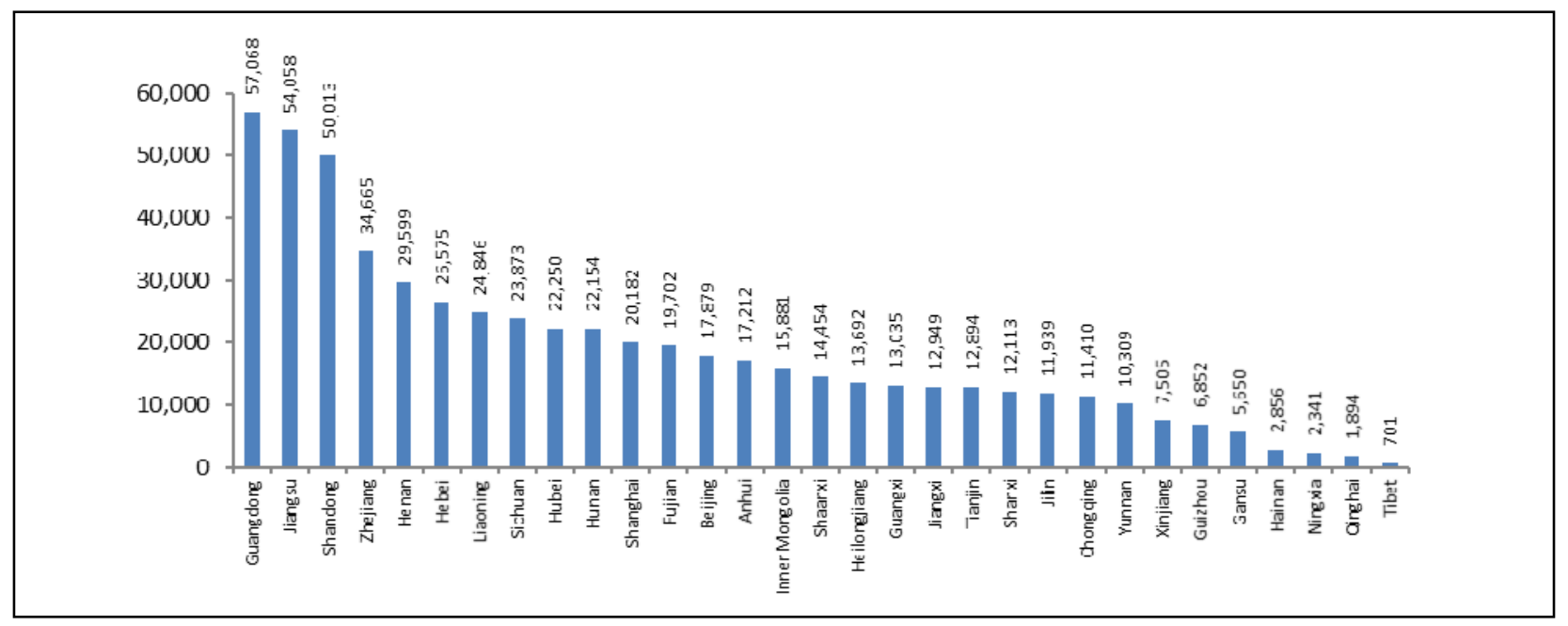

Figure 15a. GDP by regions in China in 2013 (Yuan). Source: China Statistics.

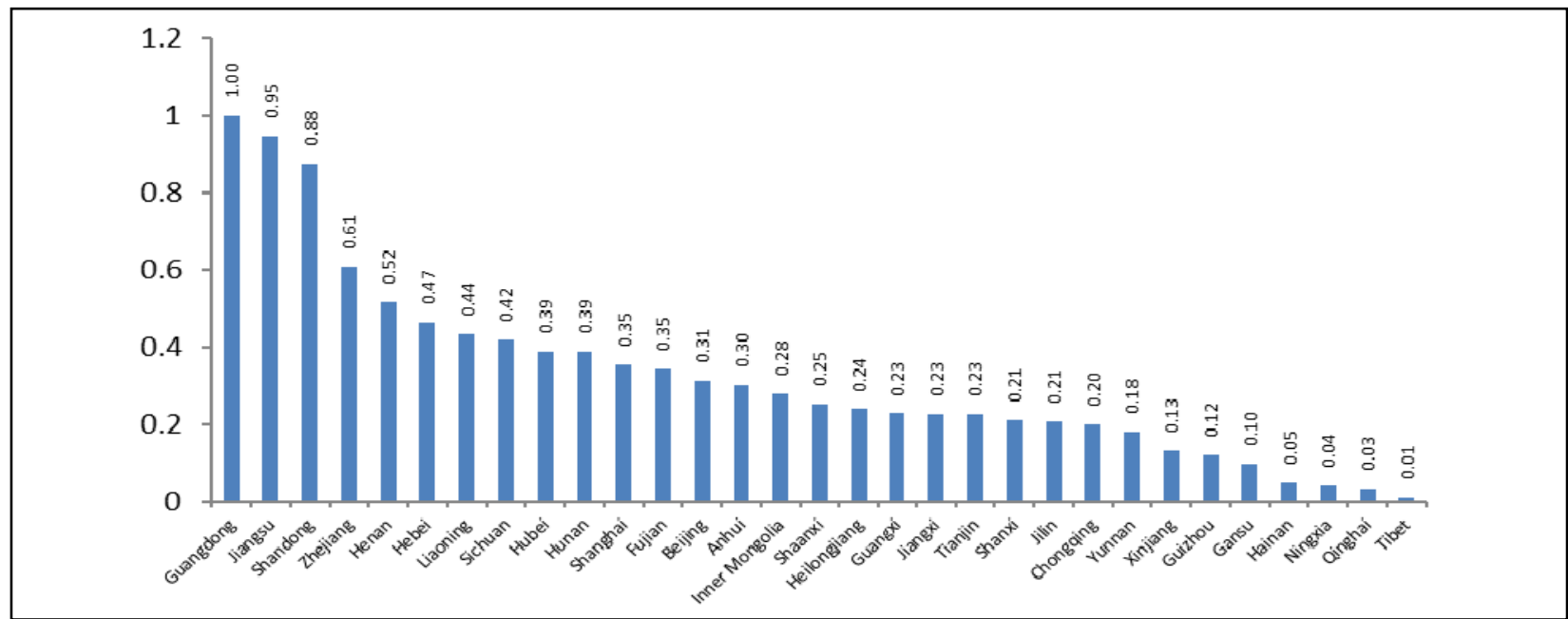

Figure 15b. Relative GDP of provinces in China (2013). Source: China Statistics.

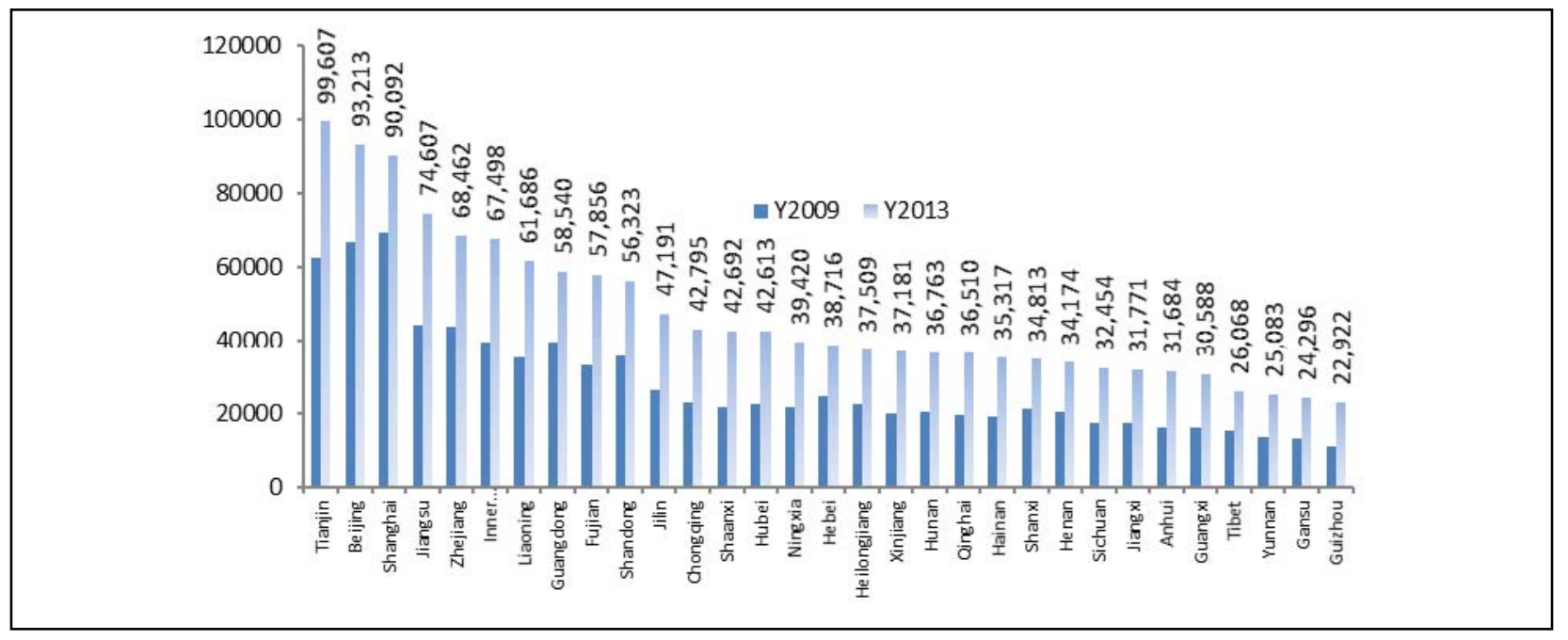

Figure 16. Per capita GDP in China in 2009 and 2013 (Yuan). Source: China Statistics. 


\section{Literature on the Chinese Economy}

Literature on the Chinese economy has been growing rapidly after it started democratic liberalisation programmes in 1879. Studies vary in their focus. Whalley (2015) is large edited volumes titled Asia and the World Economy relating Asian and Chinese economies to the global economy. Chow (2016) is an attempt to project the Chinese economy as a global leader. Xu (2011) is an excellent review on the various aspects of analysis relating to the developments of the Chinese economy.

Early study on reforming China's economic system, Perkins (1988) focused on transformation ownership of firms and subsequent improvement in productivity. Then Wang (1991) proposed a behavioural model based on the Chinese experience. He also focused on issues such as economic reform, fixed capital investment expansion, and inflation. Gradually researchers became concerned about the regional income inequality and economic growth in China (Chen \& Fleisher, 1996). They were also leaders, managers, and the organization of township and tillage Enterprises in China (Chen \& Rozelle, 1999).

Second waves of studies then started on evaluating economic performance of China after successful implementation of export oriented growth strategies. Chow and $\mathrm{Li}$ (2002) looked into economic growth between 1952-2010. Young (2000) assesses distortions and incremental reform in the evolving system. Then Lau, Qian, and Roland (2000) review the dual track approach to development in China where reforms were benefiting every one without Losers. Lin and Liu (2000) attribute it to fiscal decentralization and economic growth.

Chen, Li, and Zhou (2005) analyse importance of economic management at local levels and relative performance evaluation and turnover of provincial leaders in China. The space of transition from the village to an industrial economy is explained by Kung, and Lin (2007) explains how the village and town enterprises were replaced by the more large scale production process in China. Issues of public private partnership and soft budget constraints are explained in the work of Lin and Li (2008) and Fu, Abroakwa, and Bhattarai (2014). Xu (2011) is a very comprehensive review on the economic development process in China and he examines fundamental institutions of China's reforms and development. There are issues also relating to the importance of political connections in getting access to key services such as the bank lines of credit (Luo \& Qianwei, 2014).

Recently focus of economic research has been on macroeconomic impacts of Chinese currency appreciation (Yang, Zhang, \& Tokgoz, 2013). They used a global CGE analysis for this. Whiel Wan-Chun Liu and Hsu (2014) discuss profit performance of financial holding companies from Taiwan, and Zhu, Whalley, and Zhao (2014) have investigated issues on intergenerational transfer, human capital and long-term growth in China under the one child policy. Similarly Zhou (2014) examines income diversification on bank risk. Volumes of edited by Whalley (2015) contain analysis of sustainability and growth, comparative study of India and China and actions on climate changes. Chow (2016) examines China as a leader of the world economy.

Despite all above studies it is very difficult to see any realistic analysis based on the dynamic CGE model of the Chinese economy. This study aims to fill this gap in the literature on Chinese economic growth and redistribution.

Development of the Chinese financial system has remained at the centre of this development process. Studies of addition Hansen (2014), Fama (2014), Shiller (2014), and Weale (2014) provide theoretical insights 
in the development of Chinese economy. On the empirical aspect Bhattarai (2015) explains the dynamic CGE model of China for analysis of financial deepening issues. Zhou (2014), Luo and Ying (2014), Zhu, Whalley, and Zhao (2014), Fu, Abrokwa, and Bhattarai (2014), Hsua, Tian, and Xua (2014), Liu and Hsu (2014) review issues relating to the role of public and private sectors in the Chinese economy.

FDI growth and regional inequality issues are studied by Aghion, Van Reenen, and Zingales (2013), Huang, Whalley, and Zhang (2013), Bhattarai and Mallick (2013), Yang, Zhang, and Tokgoz (2013). They also conclude that:

There are huge and widening gaps between the rural and urban income and consumption across 32 provinces of China. Chinese policy makers switched to a non-linear optimisation model of consumption pursuing rapid urbanisation and export oriented growth strategy since 1978. Rural areas are becoming poorer relative to urban ones and likely to be so in coming years unless export oriented growth strategies are accompanied by domestic consumption based growth strategies as proposed in the linear optimisation model of consumption.

Similarly to Xu (2011) for China Kotwal, Ramaswami, and Wadha (2011) compare growth strategies and prospects for India. Su and Zheng (2011), Li (2011), Miller and Stiglitz (2010), Brunnermeier (2009), Du and Xu (2009), Bosworth and Collins (2008), Lin, Yifu, and Li (2008), Jefferson, Rawski, and Zhang (2008) deal on financial and growth aspects of China.

\section{A Dynamic CGE Model of China}

This is model for the price based on market economy. Infinitely lived households decide over consumption and saving, leisure and labour supply. They equalise marginal utility of consumption across commodities over time. Profit maximising producers make decisions on investment and investment equalising marginal product of capital. Capital accumulation is key to economic growth process.

Households maximise life time utility subject to their wealth constraint. Investors maximise profits subject to arbitrage conditions in capital markets. Producers minimise costs subject to technology constraints. Unit profits are zero in all production sectors. Markets for goods and services are clear.

Model deals conflict and coexistence between the private and public sectors of the economy. Central and local governments engage in tax and transfer system to influence production, consumption, and distribution of income. This process creates distortions but also benefits economic agents through provision of public services. Traders optimise by Armington type differentiation in products.

Revenue and expenditure of government balance (in each time or over period). Trade is balanced in each period or over time. Economy grows at steady state rate beyond the model horizon $T$.

Dimensions and parameters in the dynamic CGE tax model of China are shaped by the order of the input-output table available from the OECD. There are 34 production sectors and supply sectors. Main sectors are agriculture, extraction and other mining, chemicals, metals, engineering, food and drink, other manufacturing, utilities, construction, distribution, transport, financial, public administration, education, health and housing. Sector specific capital is formed from the investment in each period. Labour input grows at an exogenous rate.

Time horizon of this model expands from 2006 to 2040 years. Equilibrium between demand and supply is determined by a set of behavioural and policy parameters and endowments. The major behavioural parameters are shares and elasticities of substitution in preferences (inter and intra temporal) and technology (nested production function), and trade (differentiated product assumption) and accumulation: rate of depreciation and 
discount. It also includes endowments, initial and terminal capital. Then it includes labour market and fiscal policy parameters including tax rates on capital income, labour income, and final demand.

Use of the dynamic general equilibrium tax model will be for analysis of sector specific growth paths of output, employment, investment, and capital stock. It also helps to construct the dynamic efficiency analysis across sectors and households. Welfare measures, total of backward and forward linkages, capital accumulation levels are consistent to the initial and terminal capital stocks, rates of saving and investment over time. Among others policy analysis consists of finding of the impact of golden rule of fiscal policy, existence or non existence of Ricardian equivalence, intertemporal balance in budget and intertemporal redistribution. Model determines the optimal rate of saving and can be employed in examination of the impacts of different rules of balance in trade and payment.

Model results need to be contrasted to the literature in tax policy analysis. Are the results consistent to the Adam Smith's Cannon of taxes: Equity, efficiency, sanctions and economy? Are results confirming to the principles of the classical free market economy including the minimum government and transparent taxes? Do they comply with the Dalton's principles of taxes particularly regarding the Pareto efficiency the basis of tax? What additional insights can one get over the partial equilibrium analysis of Marshall-Hicks-Atkinson on prices, supply and demand in goods and factor markets? Are the results comparable to other studies on impact of taxes in macroeconomic models including those from the macro-modelling bureau, Treasury, BOE, NIESR, IFS, Cambridge, LBS, Warwick, Liverpool, Exeter, Hull or from Keynes, Stones, Klein, Wallis, Weale, Minford, Scott? Are these results appropriate to the taxes on economic growth models Golden rule of fiscal policy?

\section{General Equilibrium Impact of Taxes}

Full impact of changes in taxes occurs through several rounds. First round effects start with the incidence of tax reduction (increase) in the household income. It can happen as taxes affect profit of firms. These have impacts on demand for products by households and foreigners and supply of goods and services by firms. Similarly it affects government spending and investment spending. Second round effects occur when the burden of taxes start shifting gradually. It manifests itself as an increase or decrease in prices of commodities, collection of revenues. Final impacts are settled when all burdens shift through-out the economy. Impact of taxes here is similar to Bhattarai $(2007 ; 2014)$ model of the UK and emerging economies regarding financial deepening and economic growth. The detailed specification of this model is as follows:

Preferences and Demand for Goods and Services

$$
\begin{gathered}
\sum_{t=0}^{\infty} \beta^{t} \frac{U_{t}^{1-\sigma}-1}{1-\sigma} \\
U\left(C_{t}, L_{t}\right)=\left(\alpha_{c} C_{t}^{\frac{\gamma-1}{\gamma}}+\left(1-\alpha_{c}\right) L_{t}^{\frac{\gamma-1}{\gamma}}\right)^{\frac{\gamma}{\gamma-1}}
\end{gathered}
$$

Life Time Budget Constraints: households get income from labour and capital

$$
\begin{gathered}
\sum_{t=0}^{\infty} R_{t}^{-1}\left(P_{t}\left(1+t^{v c}\right) C_{t}+w_{t}\left(1-t_{l}\right) L_{t}\right)=W \\
W=\frac{J_{0}}{1+r_{0}^{c}}+\frac{J_{1}}{\left(1+r_{0}^{c}\right)\left(1+r_{1}^{c}\right)}+\ldots .+\frac{J_{2}}{\Pi_{s}^{t}\left(1+r_{s}^{c}\right)}+\ldots=\sum_{t=0}^{\infty} R_{t}^{-1} J_{t}
\end{gathered}
$$




$$
\begin{gathered}
J_{t}=\left(1-t_{l}\right) w_{t} \bar{L}_{t}+\left(1-t_{k}\right) r_{t} K_{t}+T R_{t} \\
\mathfrak{I}=\sum_{t=0}^{\infty}\left(\frac{1}{1+\rho}\right)^{t} \frac{\left(\left(\alpha_{c} C_{t}^{\frac{\gamma-1}{\gamma}}+\left(1-\alpha_{c}\right) L_{t}^{\frac{\gamma-1}{\gamma}}\right)^{\frac{\gamma}{\gamma-1}}\right)^{1-\sigma}-1}{1-\sigma}+\lambda\left[\sum_{t=0}^{\infty} R_{t}^{-1}\left(P_{t}\left(1+t^{v d}\right) C_{t}+w_{t}\left(1-t_{l}\right) L_{t}\right)-W_{t}\right] \\
R_{t}^{-1}=\prod_{s=0}^{t-1} \frac{1}{1+r_{s}} ; \quad P_{t}=\vartheta \prod_{i=1}^{n} \alpha_{i} p_{i, t}^{\alpha_{i}} ; \quad S_{t}=J_{t}-P_{t}\left(1+t^{v c}\right) C_{t}
\end{gathered}
$$

Production and Supply

$$
\begin{gathered}
\Pi_{j, t}^{y}=\left[\left(\left(1-\delta_{i}^{e}\right) P D_{i, t}^{\frac{\sigma_{y}-1}{\sigma_{y}}}+\delta_{i}^{e} P E_{i, t}^{\frac{\sigma_{y}-1}{\sigma_{y}}}\right)\right]^{\frac{1}{\sigma_{y}-1}}-\theta_{j}^{v} P Y_{j, t}^{v}-\theta_{j}^{d} \sum_{i} a_{i, j}^{d} P_{i, t}-\theta_{j}^{m} \sum_{i} a_{i, j}^{m} P M_{j, t} \\
Y_{i, t}=\Omega_{i}\left(\left(1-\delta_{i}\right)\left(K_{i, t}\right)^{\gamma_{i}}+\delta_{i}\left(L S_{i, t}\right)^{\gamma_{i}}\right)^{\frac{1}{\gamma_{i}}} \\
P Y_{i, t} Y_{i, t}=w_{t} L S_{i, t}+r_{t} K_{i, t} \\
G Y_{i, t}=\min \left(Y_{i, t}\left(\frac{D I_{i, j, t}}{a_{i, j}^{d}}\right)_{i=j},\left(\frac{M I_{i, j, t}}{a_{i, j}^{m}}\right)_{i=j}\right)
\end{gathered}
$$

Trade and Absorption

$$
\begin{gathered}
A_{i, t}=\Phi\left(\left(\delta_{i}^{d}\right) \frac{1}{\sigma_{m}} D_{i, t}^{\frac{\sigma_{m}-1}{\sigma_{m}}}+\left(\delta_{i}^{m}\right) \frac{1}{\sigma_{m}} M_{i, t}^{\frac{\sigma_{m}-1}{\sigma_{m}}}\right)^{\frac{\sigma_{m}}{\sigma_{m}-1}} \\
P A_{i, t} A_{i, t}=P D_{i, t} D_{i, t}+P M_{i, t} M_{i, t} \\
G Y_{i, t}=\Theta\left(\left(1-\delta_{i}^{e}\right) D_{i, t}^{\frac{\sigma_{y}-1}{\sigma_{y}}}+\delta_{i}^{e} E_{i, t}^{\frac{\sigma_{y}-1}{\sigma_{y}}}\right)^{\frac{\sigma_{y}}{\sigma_{y}-1}} \\
A_{i, t}=C C_{i, t}+G_{i, t}+I_{i, t}+\sum_{j} D I_{i, j, t}+\sum_{j} M I_{i, j, t}
\end{gathered}
$$

Trade and BOP Constraint:

$$
\begin{gathered}
\sum_{i} P E_{i, t} E_{i, t}=\sum_{i} P M_{i, t} M_{i, t} \\
\sum_{t}\left(1+r^{W}\right)^{-t} \sum_{i} P E_{i, t} E_{i, t}=\sum_{t}\left(1+r^{W}\right)^{-t} \sum_{i} P M_{i, t} M_{i, t}
\end{gathered}
$$

Tax Revenue and Public Spending 


$$
\begin{gathered}
R E V_{t}=\sum_{i} t_{i}^{k} r_{t} K_{i, t}+\sum_{i} t_{i}^{v c} P_{i, t} C C_{i, t}+\sum_{i} t_{i}^{v g} P_{i, t} G_{i, t}+\sum_{i} t_{i}^{v k} P_{i, t} I_{i, t}+\sum_{i} t_{t} w L S_{t}+\sum_{i} t_{i}^{m} P M_{i, t} M_{i, t}+\sum_{i} t_{i}^{p} P_{i, t} G Y_{i, t} \\
R E V_{t}=G_{t}+T R_{t} \\
G=\sum_{i} P A_{i} G D_{i}+\sum_{i} P A_{i} G M_{i}
\end{gathered}
$$

The major feature of an inter-temporal competitive general equilibrium model is that demand equals supply in equilibrium in all periods in labour, capital, and goods markets. Trade and government budget is balanced over time. Equilibrium is guaranteed by the relative prices that guarantee the demand equals supply in each market. These prices in turn are determined in terms of behavioural parameters such as shares of spending, costs and the elasticities of substitution in preferences (inter and intra temporal), technology (nested production function) trade (differentiated product assumption) accumulation as given in Table 2. Other parameters that determine relative prices include depreciation and discount rates, fiscal policy parameters such as tax rates on capital income, labour income and final demand as well as endowments initial and terminal capital and labour (see Appendix A).

\section{Definition of a Competitive Equilibrium in the Economy}

A competitive equilibrium is given by the set prices of composite commodities, $P_{i, t}$; prices of domestic goods sold in domestic markets, $P D_{i, t}$; prices of exported commodities, $P X_{i, t}$; prices of capital goods , $P_{j, t}^{k}$; prices of terminal capital , $P T K_{j, t}$; wage rates for each categories of labor, $W_{h, t}$; prices of government services, $P G_{t}$; prices of provisions for tourism, $P T_{t}$; prices of transfer, $P R_{t}$; prices of consumption, $P U_{t}$; price of aggregate welfare, ${ }_{P W_{t}}$; price of foreign exchange, $P F X_{t}$; present value of foreign exchange, $P V P F X_{t}$; rental rate of capital for each sector, $r_{1}^{k}: \mathrm{R}_{+} \rightarrow \mathrm{R}$, and sequence of gross output, $Y_{i, t}$; total supply of commodities, $A_{i, t}$; sectoral capital stock, $K_{i, t}$; sectoral investment, $I_{i, t}$; exports, $X_{i, t}$; government services, $G O V_{t}$; level of household utility from consumption, $U_{t}$; and total welfare, $W$ such that given these prices and commodities such that

- households solve intertemporal utility maximization problems;

- investors solve intertemporal profit maximization problem;

- markets for goods and services, labor, capital clear;

- government constraint is satisfied;

- and balance of payments condition is fulfilled.

Table 2

Basic Parameters of the China's DCGE Model

\begin{tabular}{|l|l|}
\hline Steady state growth rate for sectors $(\mathrm{g})$ & 0.08 \\
\hline Net interest rate in non-distorted economy (r) & 0.05 \\
\hline Reference quantity for each sector, $Q_{r f}$ & $(1+g)^{t-1}$ \\
\hline Reference price for each sector, $P_{r f}$ & $1 /(1+r)^{t-1}$ \\
\hline Elasticity of transformation between China's domestic supplies and exports to the Rest of the World (ROW), $\sigma_{y}$ & 1.5 \\
\hline Elasticity of substitution between domestic products and imports from Rest of the World (ROW), $\sigma_{m}$ & 1.0 \\
\hline Intertemporal elasticity of substitution, $\sigma$ & 1.25 \\
\hline Intra temporal elasticity of substitution in public consumption & 1.0 \\
\hline Elasticity of substitution in consumption goods across sectors, $\sigma c$ & 1.0 \\
\hline
\end{tabular}




\section{Analysis of Results}

In general the results of model are as expected. Current system of tax and transfer policies leads to steady growth of the Chinese economy (Figure 17). Growth path of real output differs significantly with the tax reforms from that without the tax reforms (Figure 18). Wage bill is lower in the tax reform scenario than that without the reforms (Figure 19). Consumption of households increases under the tax reform significantly (Figure 20). It will be lower without tax reform (Figures 22 and 23). There are some reallocation effects on the welfare levels of households as economy evolves (Figure 21).

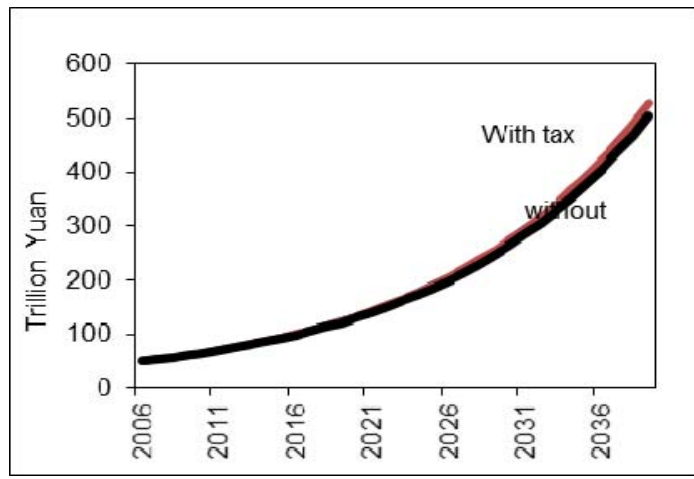

Figure 17. Level of real output.

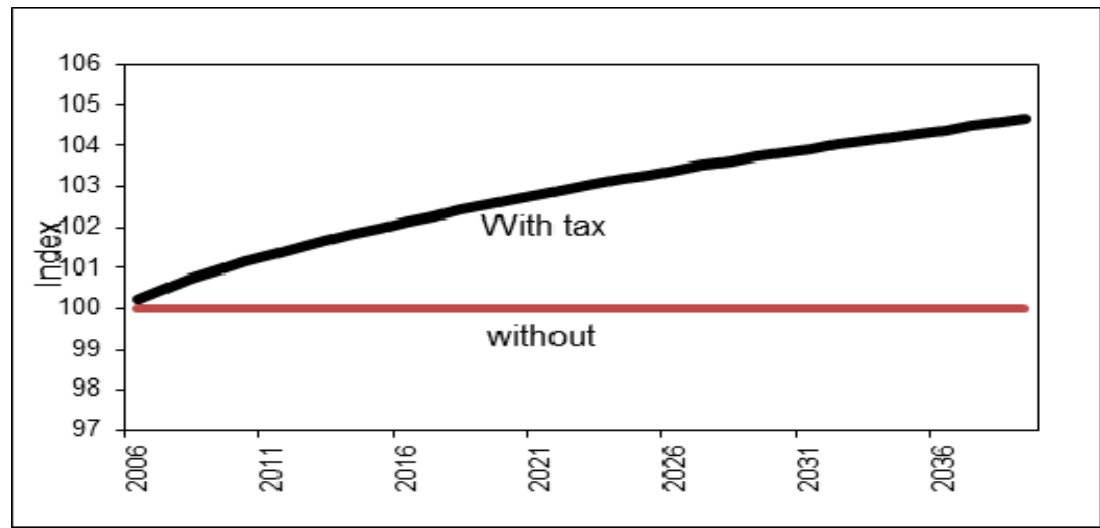

Figure 18. Real output under the tax reforms relative to the benchmark.

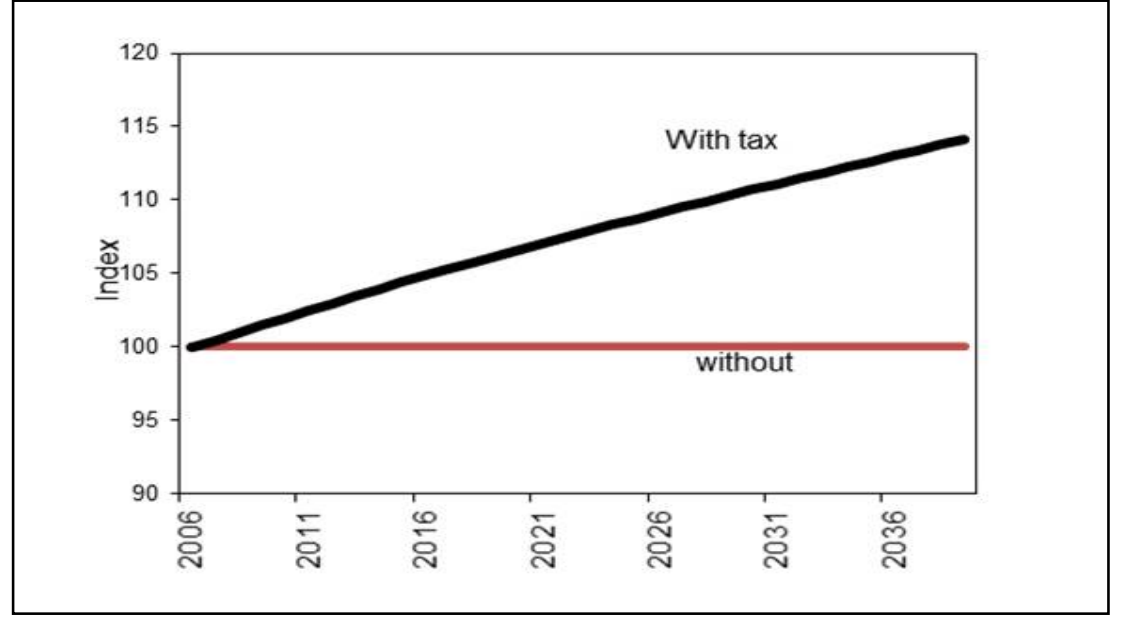

Figure 19. Capital stock under the tax reforms relative to the benchmark. 


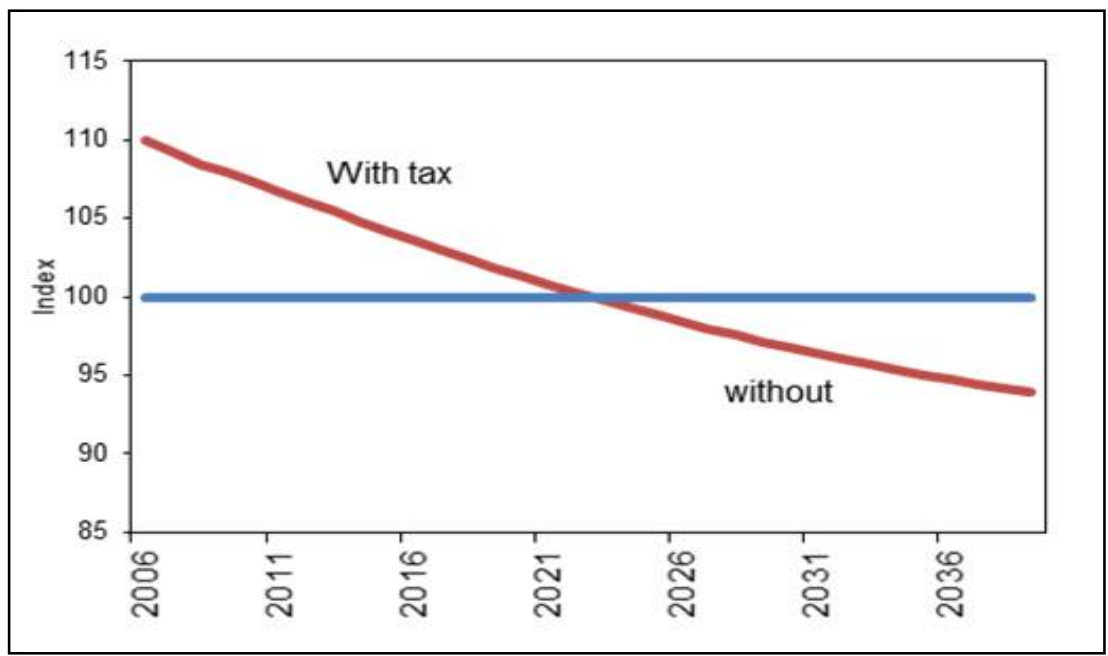

Figure 20. Wage-bill under the tax reforms relative to the benchmark.

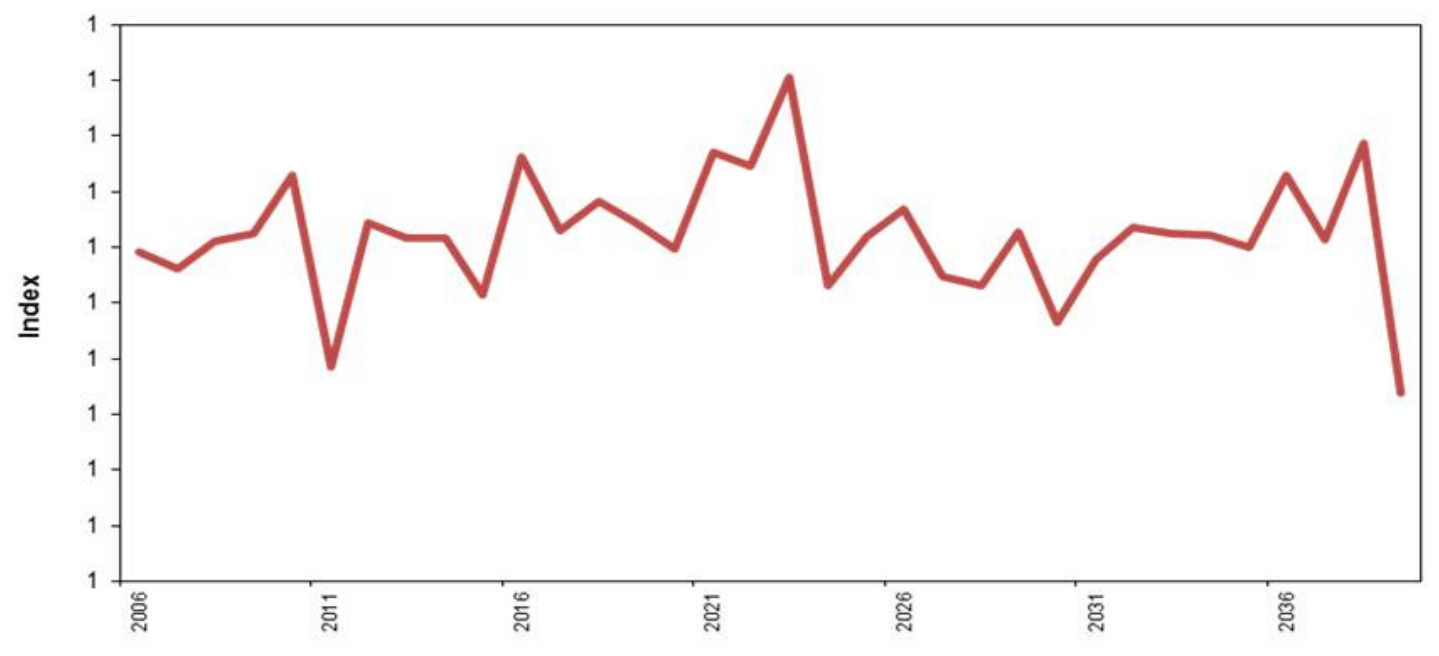

Figure 21. Total utility under the tax reforms relative to the benchmark.

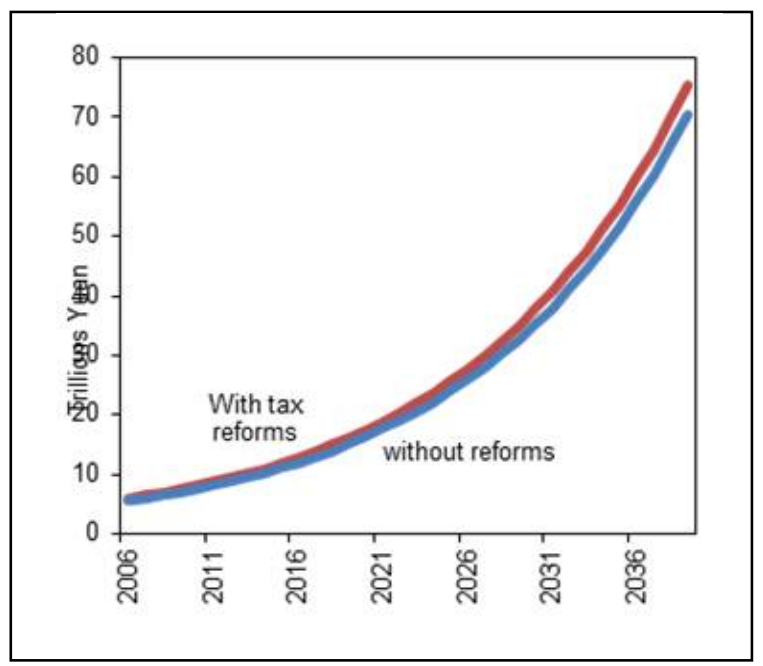

Figure 22. Consumption level under the tax reforms relative to the benchmark. 


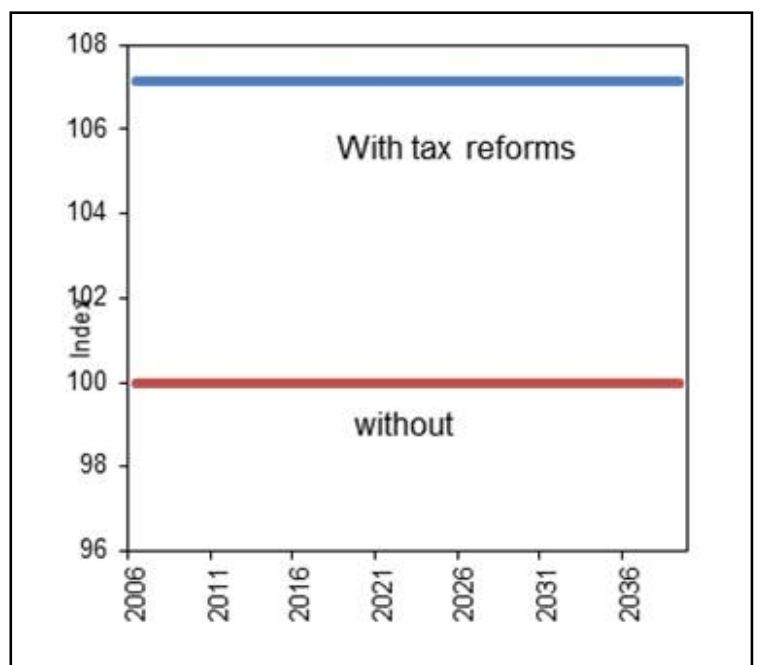

Figure 23. Consumption under the tax reforms relative to the benchmark.

\section{Conclusions}

A dynamic CGE model of China is constructed on the basis of input-output data obtained from the OECD for mid 2000s. Structure of output, investment, consumption, production, public sector, and trade are studied referring dataset obtained from the Statistical Bureau of China. Efficiency and redistribution impacts of tax reforms are considered for multi-sectoral and multi-household model of the Chinese economy with decentralised markets and governments involved in tax, spending, and borrowing. Results of analysis illustrate how tax reforms benefit the Chinese economy over years not only by raising the production but also consumption of households and capital accumulation for the entire economy. Efficiency and redistribution impacts are very significant as illustrated in the series of graphs showing the evolution of the Chinese economy in the next half century.

\section{References}

Aghion, P., Van Reenen, J., \& Zingales, L. (2013). Innovation and institutional ownership. American Economic Review, 103(1), 277-304.

Ahlers, J. (1946). Postwar banking in Shanghai. Pacific Affairs, 19(4), 384-393.

Auerbach, A. J., Kotlikoff, L. J., \& Koehler, D. (2016). U.S. inequality, fiscal progressivity, and work disincentives: An intragenerational accounting. Retrieved from http://kotlikoff.net/

Bhattarai, K. (2015). Financial deepening and economic growth in advanced and emerging economies. The Review of Development Economics, 19(1), 178-195.

Bhattarai, K. N., \& Chen, N. (2013). Rural urban income and consumption gaps across provinces of China, 1978-2008. 2 (2), 70-77.

Bhattarai, K. (2007). Welfare impacts of equal-yield tax experiment in the UK economy. Applied Economics, 39, 1545-1563.

Bhattarai, K., \& Mallick, S. (2013). Impact of China's currency valuation and labour cost on the US in a trade and exchange rate model. North American Journal of Economics and Finance, 25, 40-59.

Bosworth, B., \& Susan, M. C. (2008). Accounting for growth: Comparing China and India. The Journal of Economic Perspectives, 22(1), 45-66.

Brunnermeier, M. K. (2009). Deciphering the liquidity and credit crunch 2007-2008. Journal of Economic Perspectives, 23(1), 77-100.

Chen, H. Y., \& Scott, R. (1999). Leaders, managers, and the organization of township and village enterprises in China. Journal of Development Economics, 60(2), 529-557.

Chen, J., \& Fleisher, B. M. (1996). Regional income inequality and economic growth in China. Journal of Comparative Economics, 22(2), 141-164. 
Chen, Y., Li, H., \& Zhou, L. A. (2005). Relative performance evaluation and the turnover of provincial leaders in China. Economics Letters, 88(3), 421-425.

Chow, G. C. (2016). China as a leader of the world economy. World Scientific.

Chow, G. C., \& Li, K. W. (2002). China’s economic growth: 1952-2010. Economic Development and Cultural Change, 51(1), 247-256.

Diamond, D. W., \& Dybvig, P. H. (1983). Bank runs, deposit insurance, and liquidity. Journal of Political economy, 91(3), 401-419.

Du, J., \& Xu, C. (2009). Which firms went public in China? A study of financial market regulation. World Development, 37(4), 812-824.

Fama, E. F. (2014). Two pillars of asset pricing. American Economic Review, 104(6), 1467-1485.

Fry, M. J. (1978). Money and capital or financial deepening in economic development? Journal of Money, Credit and Banking, 10(4), 464-475.

$\mathrm{Fu}, \mathrm{X}$. (2004). Limited linkages from growth engines and regional disparities in China. Journal of Comparative Economics, 32(1), 148-164.

Fu, T., Abrokwa, K. K., \& Bhattarai, K. R. (2014). Impacts of securities transaction tax adjustments in stock market in China. Advances in Economics and Business, 2(7), 249-260.

Gordon, R. H., \& Li, W. (2003). Government as a discriminating monopolist in the financial market: The case of China. Journal of Public Economics, 87(2), 283-312.

Hansen, L. P. (2014). Nobel lecture: Uncertainty outside and inside economic models. Journal of Political Economy, 122(5), 945-987.

Hsua, P. H., Tian, X., \& Xua, Y. (2014). Financial development and innovation: Cross-country evidence. Journal of Financial Economics, 112(1), 116-135.

Huang, Y. (1996). Central-local relations in china during the reform era: The economic and institutional dimensions. World Development, 24(4), 655-672.

Huang, H., Whalley, J., \& Zhang, S. (2013). Multiple Nash equilibria in tariff games. Applied Economics Letters, 20(4), 332-342.

Jefferson, G. H., Rawski, T. G., \& Zhang, Y. (2008). Productivity growth and convergence across China’s industrial economy. Journal of Chinese Economic and Business Studies, 6(2), 121-140.

Jin, H., Qian, Y., \& Weingast, B. R. (2005). Regional decentralization and fiscal incentives: Federalism, Chinese style. Journal of Public Economics, 89(9), 1719-1742.

Kanbur, R., \& Zhang, X. (2005). Fifty years of regional inequality in China: A journey through central planning, reform, and openness. Review of Development Economics, 9(1), 87-106.

Kung, J. K. S., \& Lin, Y. M. (2007). The decline of township-and-village enterprises in China's economic transition. World Development, 35(4), 569-584.

Kotwal, A., Ramaswami, B., \& Wadhwa, W. (2011). Economic liberalization and Indian economic growth: What's the evidence? Journal of Economic Literature, 49(4), 1152-1199.

Lau, L. J., Qian, Y., \& Roland, G. (2000). Reform without losers: An interpretation of China’s dual-track approach to transition. Journal of Political Economy, 108(1), 120-143.

Levine, R. (1997). Financial development and economic growth: Views and agenda. Journal of Economic Literature, 35(2), 688-726.

Li, L. (2011). The incentive role of creating “cities” in China. China Economic Review, 22(1), 172-181.

Lin, J. Y., \& Li, Z. (2008). Policy burden, privatization and soft budget constraint. Journal of Comparative Economics, 36(1), 90-102.

Lin, J. Y., \& Liu, Z. (2000). Fiscal decentralization and economic growth in China. Economic Development and Cultural Change, 49(1), 1-21.

Li, W., \& Yang, D. T. (2005). The great leap forward: Anatomy of a central planning disaster. Journal of Political Economy, 113(4), 840-77.

Luo, D., \& Ying, Q. (2014). Political connections and bank lines of credit. Emerging Markets Finance and Trade, 50(3), 5-21.

Liu, W. C., \& Hsu, C. M. (2014). Profit performance of financial holding companies: Evidence from Taiwan. Emerging Markets Finance and Trade, 50(3), 190-200.

Maskin, E., \& Tirole, J. (1990). The principal-agent relationship with an informed principle: The case of private values. Econometrica, 58(2), 379-410. 
McKinnon, R. I. (1973). Money and capital in economic development. Washington D.C.: The Brookings Institution.

Miller, M., \& Stiglitz, J. (2010). Leverage and asset bubbles: Averting Armageddon with Chapter 11? The Economic Journal, 120(544), 500-518.

Perkins, D. H. (1988). Reforming China’s economic system. Journal of Economic Literature, 26(2), 601-645.

Raghuram, G. R., \& Zingales, L. (1998). Financial dependence and growth. American Economic Review, 88(3), 559-586.

Shaw, E. S. (1973). Financial deepening in economic development. New York: Oxford University Press.

Shiller, R. J. (2014). Speculative asset prices. American Economic Review, 104(6), 1486-1517.

Sinn, H. W. (2010). Casino capitalism. Oxford: Oxford University Press.

Su, Y., \& Zheng, L. (2011). The impact of securities transaction taxes on the Chinese stock market. Emerging Markets Finance and Trade, 47, 32-46.

Townsend, R. M., \& Ueda, K. (2006). The financial deepening, inequality, and growth: A model-based quantitative evaluation. Review of Economic Studies, 73(1), 251-280.

Yang, J., Zhang, W., \& Tokgoz, S. (2013). Macroeconomic impacts of Chinese currency appreciation on China and the rest of world: A global CGE analysis. Journal of Policy Modelling, 35(6), 1029-1042.

Young, A. (2000). The razor's edge: Distortions and incremental reform in the People’s Republic of China. Quarterly Journal of Economics, 115(4), 1091-1135.

$\mathrm{Xu}$, C. (2011). The fundamental institutions of China's reforms and development. Journal of Economic Literature, 49(4), 1076-1151.

Wang, Y. (1991). Economic reform, fixed capital investment expansion, and inflation: A behavioral model based on the Chinese experience. China Economic Review, 2(1), 3-27.

Weale, M. (2014). What to do when we don't know policy-making when spare capacity is uncertain. Bank of England.

Whalley, J. (2015). Asia and the World Economy. World Scientific Reference on Growth, Economics and Crisis in Asia.

Zhu, X., Whalley, J., \& Zhao, X. (2014). Intergenerational transfer, human capital and long-term growth in China under the one child policy. Economic Modelling, 40, 275-283.

Zhou, K. (2014). The effect of income diversification on bank risk: Evidence from China. Emerging Markets Finance \& Trade, 50, 201-213. 
Appendix A. Share of Different Sources of Tax Revenue

\begin{tabular}{llllllll}
\hline & Total & VAT & Consumption tax & Business tax & Corporate tax & Income tax & Tariffs \\
\hline 1999 & 1.00 & 0.36 & 0.08 & 0.16 & 0.08 & 0.04 & 0.05 \\
2000 & 1.00 & 0.36 & 0.07 & 0.15 & 0.08 & 0.05 & 0.06 \\
2001 & 1.00 & 0.35 & 0.06 & 0.13 & 0.17 & 0.07 & 0.05 \\
2002 & 1.00 & 0.35 & 0.06 & 0.14 & 0.17 & 0.07 & 0.04 \\
2003 & 1.00 & 0.36 & 0.06 & 0.14 & 0.15 & 0.07 & 0.05 \\
2004 & 1.00 & 0.37 & 0.06 & 0.15 & 0.16 & 0.07 & 0.04 \\
2005 & 1.00 & 0.38 & 0.06 & 0.15 & 0.19 & 0.07 & 0.04 \\
2006 & 1.00 & 0.37 & 0.05 & 0.15 & 0.20 & 0.07 & 0.03 \\
2007 & 1.00 & 0.34 & 0.05 & 0.14 & 0.19 & 0.07 & 0.03 \\
2008 & 1.00 & 0.33 & 0.05 & 0.14 & 0.21 & 0.07 & 0.03 \\
2009 & 1.00 & 0.31 & 0.08 & 0.15 & 0.19 & 0.07 & 0.02 \\
2010 & 1.00 & 0.29 & 0.08 & 0.15 & 0.18 & 0.07 & 0.03 \\
2011 & 1.00 & 0.27 & 0.08 & 0.15 & 0.19 & 0.07 & 0.03 \\
2012 & 1.00 & 0.26 & 0.08 & 0.16 & 0.20 & 0.06 & 0.03 \\
2013 & 1.00 & 0.26 & 0.07 & 0.16 & 0.20 & 0.06 & 0.02 \\
\hline
\end{tabular}

\section{Appendix B}

I appreciate a high level 18-member delegation from the Fujian province of China visited the Hull University Business School on 10 December, 2015 under the initiative of the Sino-UK Link Office in London. Members of this delegation were directors and officials of tax administration institutions in Fujian. This was a follow up on a study visit by a similar delegation of educators or directors or mayors of the major cities in the Sichuan and Yunnan provinces in October and November in 2014. Many thanks for them for encouraging me to do this research; their details are given below. I also appreciate PhD students and other faculty members who attended to these presentations.

Members of the 20-member delegation Fujian Province (10 December 2015):

\begin{tabular}{|l|l|l|}
\hline No. & Name & Position \& Occupation \\
\hline 1 & Ms. Yang Jun & Deputy Director, Fujian Local Taxation Bureau \\
\hline 2 & Ms. Zou Lihong & Division Director, Department of Tax Service, Fujian Local Taxation Bureau \\
\hline 3 & Mr. Li Dong & Consultant, Ticket Equipment Branch, Fujian Local Taxation Bureau \\
\hline 4 & Mr. Liu Zhentai & Consultant, Ticket Equipment Branch, Fujian Local Taxation Bureau \\
\hline 5 & Ms. Xiao Zhen & Deputy Director, Department of Supervision, Fujian Local Taxation Bureau \\
\hline 6 & Ms. Tao Jing & Deputy Division Director, Department of Information Technology, Fujian Local Taxation Bureau \\
\hline 7 & Ms. Hong Li & Deputy Division Director, Department of Personnel and Education, Fujian Local Taxation Bureau \\
\hline 8 & Ms. Chen Xiaoru & Associate Consultant, Planning and Finance Department, Fujian Local Taxation Bureau \\
\hline 9 & Xie Shaohui & Director, Mawei Local Taxation Bureau, Fuzhou City, Fujian Province \\
\hline 10 & Mr. Zheng Jianghui & Deputy Director, Zhangzhou Local Taxation Bureau, Fujian Province \\
\hline 11 & Mr. Chen Zhicong & General Economist, Quanzhou Local Taxation Bureau, Fujian Province \\
\hline 12 & Mr. Zhou Zhiwang & Deputy Director, Putian Local Taxation Bureau, Fujian Province \\
\hline 13 & Mr. Lin Jinqiu & Deputy Director, Sanming Local Taxation Bureau, Fujian Province \\
\hline 14 & Mr. Hong Hui & Deputy Director, Sanming Local Taxation Bureau, Fujian Province \\
\hline 15 & Mr. Tang Riping & Deputy Director, Longyan Local Taxation Bureau, Fujian Province \\
\hline 16 & Mr. Yan Hongyan & Deputy Director, Pingtan Comprehensive Experiential Area Local Taxation Bureau, Fujian Province \\
\hline 17 & Ms. Gao Minyi & $\begin{array}{l}\text { Senior Staff Member, Tax Service Section, Local Taxation Bureau of Haicang District, Xiamen City, } \\
\text { Fujian }\end{array}$ \\
\hline 18 & Mr. Xie Genlin & Director, Caoyuan Branch of Yongan Local Taxation Bureau, Fujian Province \\
\hline
\end{tabular}


Members of the 20-member delegation from Yunnan (21 November 2014):

\begin{tabular}{|c|c|c|}
\hline No. & Tame & Position \& Occupation \\
\hline 1 & Ir. Zeng Ying & irector, Personal Finance Department, Yunnan Rural Credit Cooperatives \\
\hline 2 & Is. Qian Ruihua & Associate Consultant, Personal Finance Department, Yunnan Rural Credit Cooperatives \\
\hline 3 & Mr. Hong Guohui & $\begin{array}{l}\text { Chairman of Board of Directors, Ludian County Confederation of Rural Credit Cooperatives, } \\
\text { Yunnan Province }\end{array}$ \\
\hline 4 & Mr. Gao Rong & $\begin{array}{l}\text { Chairman of Board of Directors, Qiaojia County Confederation of Rural Credit Cooperatives, } \\
\text { Yunnan Province }\end{array}$ \\
\hline 5 & Mr. Yang Jiyong & Director, Mang City Confederation of Rural Credit, Cooperatives, Yunnan Province \\
\hline 6 & Mr. Peng Mingchang & $\begin{array}{l}\text { Chairman of Board of Directors, Lianghe County Confederation of Rural Credit Cooperatives, } \\
\text { Yunnan Province }\end{array}$ \\
\hline 7 & Mr. Li Wenwu & $\begin{array}{l}\text { Chairman of Board of Directors, Longyang District, Confederation of Rural Credit Cooperatives, } \\
\text { Yunnan Province }\end{array}$ \\
\hline 8 & Mr. Li Yuanqi & $\begin{array}{l}\text { Chairman of Board of Directors, Longling County Confederation of Rural Credit Cooperatives, } \\
\text { Yunnan Province }\end{array}$ \\
\hline 9 & Mr. Tian Songming & $\begin{array}{l}\text { Chairman of Board of Directors, Mile City Confederation of Rural Credit Cooperatives, Yunnan } \\
\text { Province }\end{array}$ \\
\hline 10 & Mr. Yang Yongming & $\begin{array}{l}\text { Chairman of Board of Directors, Jinping County Confederation of Rural Credit Cooperatives, } \\
\text { Yunnan Province }\end{array}$ \\
\hline 11 & Mr. He Feng & $\begin{array}{l}\text { Chairman of Board of Directors, Xichou County Confederation of Rural Credit Cooperatives, } \\
\text { Yunnan Province }\end{array}$ \\
\hline 12 & Mr. Li Kui & $\begin{array}{l}\text { Chairman of Board of Directors, Guangnan County Confederation of Rural Credit Cooperatives, } \\
\text { Yunnan Province }\end{array}$ \\
\hline 13 & Mr. Xiang Zhihong & $\begin{array}{l}\text { Chairman of Board of Directors, Malipo County Confederation of Rural Credit Cooperatives, } \\
\text { Yunnan Province }\end{array}$ \\
\hline 14 & Mr. Li Xiancheng & Director, Simao District Confederation of Rural Credit Coopera \\
\hline 15 & Mr. Su Daming & $\begin{array}{l}\text { Chairman of Board of Directors, Jinggu County, Confederation of Rural Credit Cooperatives, } \\
\text { Yunnan Province }\end{array}$ \\
\hline 16 & Mr. Hao Ronghua & $\begin{array}{l}\text { Chairman of Board of Directors, Midu County Confederation of Rural Credit Cooperatives, Yunnan } \\
\text { Province }\end{array}$ \\
\hline 17 & Ms. Chi Hong & Principal Staff, Credit Administration Department, Yunnan Rural Credit Cooperatives \\
\hline 18 & Mr. Shao Changbin & Deputy Section Chief, Secretariat Section, Office of Yunnan Rural Credit Cooperatives \\
\hline 19 & Mr. Zhao & Business Backbone, Business Development Department, Yunnan Rural Credit Cooperatives \\
\hline 20 & Mr. Liu Ningyu & $\begin{array}{l}\text { Vice Manager, System Security Department, Science and Technology Settlement Centre, Yunna } \\
\text { Rural Credit Cooperatives }\end{array}$ \\
\hline
\end{tabular}

Members of the 20-member delegation (October 28, 2014):

\begin{tabular}{|c|c|c|}
\hline No. & Name & Position \& Occupation \\
\hline 1 & Mr. Lei Shijie & Vice Chairman, Cadre Education Society of Sichuan Province \\
\hline 2 & Mr. Chen Jiming & Executive Deputy Mayor, the People’s Government of Zigong, Sichuan Province \\
\hline 3 & Mr. Chen Wen & $\begin{array}{l}\text { Director, State-owned Assets Supervision and Administration Commission of Luzhou, Sichuan } \\
\text { Province }\end{array}$ \\
\hline 4 & Mr. Hu Guangming & Deputy Mayor, the People’s Government of Nanchong, Sichuan Province \\
\hline 5 & Mr. Chen Jie & Deputy Mayor, the People’s Government of Guang’an, Sichuan Province \\
\hline 6 & Mr. Hu Jie & Deputy Mayor, the People’s Government of Dazhou, Sichuan Province \\
\hline 7 & Mr. Sun Jiuguo & Deputy Mayor, the People’s Government of Yaan, Sichuan Province \\
\hline 8 & Mr. Wu Xiaoke & Executive Deputy Mayor, the People’s Government of Meishan, Sichuan Province \\
\hline 9 & Mr. Shan Muzhen & $\begin{array}{l}\text { Deputy Governor, the People’s Government of Aba Tibetan and Qiang Autonomous Prefecture, } \\
\text { Sichuan Province }\end{array}$ \\
\hline 10 & Mr. Yang Chao & Deputy Director, Sichuan Rural Credit Union \\
\hline 11 & Mr. Ai Yubin & Deputy Director, Finance Office of Sichuan Provincial People’s Government \\
\hline 12 & Mr. Ren Chujun & District Mayor, Renhe District People’s Government, Pan Zhihua, Sichuan Province \\
\hline 13 & Mr. Chen Wanjian & Mayor, the People’s Government of Mianzhu, Sichuan Province \\
\hline 14 & Mr. Liu Xiangyu & District Mayor, Lizhou District People’s Government, Guangyuan, Sichuan Province \\
\hline
\end{tabular}




\begin{tabular}{|l|l|l|}
\hline 15 & Mr. Pu Congshuang & County Mayor, the People’s Government of Shehong County, Suining, Sichuan Province \\
\hline 16 & Mr. Lin Jianguo & County Mayor, the People’s Government of Pengxi County, Sichuan Province \\
\hline 17 & Mr. Ding Yinghu & County Mayor, the People's Government of Yibin County, Sichuan Province \\
\hline 18 & Mr. Li Wei & Division Director, Finance Division of Sichuan Development and Reform Commission \\
\hline 19 & Mr. Long Bin & Secretary General, Cadre Education Society of Sichuan Province \\
\hline 20 & Ms. Liu Pan & $\begin{array}{l}\text { Associate Professor, Institute of Securities and Futures, Southwestern University of Finance and } \\
\text { Economics }\end{array}$ \\
\hline
\end{tabular}

